\title{
Premature Ovarian Failure and Ovarian Autoimmunity*
}

\author{
A. HOEK, J. SCHOEMAKER, AND H. A. DREXHAGE
}

Department of Immunology (A.H.), Erasmus University, 3000 DR Rotterdam, The Netherlands; Department of Obstetrics and Gynaecology (J.S.), Academic Hospital of the Vrije Universiteit, Amsterdam, The Netherlands; and Department of Immunology (H.A.D.), Erasmus University, 3000 DR Rotterdam, The Netherlands

I. Introduction

II. Definition and Clinical Presentation of Premature Ovarian Failure (POF)

III. Cells Involved in the Immune Response
A. Antigen presentation and antigen-presenting cells, in particular dendritic cells
B. T cells
C. B cells
D. Effector cells in immune responses

IV. Tolerance to Self
A. Clonal deletion
B. Clonal anergy
C. Active immunosuppression
D. Balance between Th1 and Th2 pathways

V. Autoimmune Endocrine Disease: Developmental Stages and Genetic Predisposition

VI. POF in Association with Adrenal Autoimmunity and/or Addison's Disease
A. Antibodies in POF patients with adrenal autoim- munity and/or Addison's disease
B. Histology of ovaries in patients with POF in com- bination with adrenal autoimmunity and/or Ad- dison's disease
C. Immunogenetic aspects of POF in association with adrenal autoimmunity and/or Addison's disease
D. Conclusions

Address reprint requests to: H. A. Drexhage, Ph.D., Department of Immunology, Erasmus University, Postbus 1783, 3000 DR Rotterdam, The Netherlands.

*Work in our laboratory is funded by several grants of NWO-Health Sciences, the Dutch Diabetic Fund, and the Prevention Fund.

${ }^{1}$ The following abbreviations are used: $\operatorname{Ag}(\mathrm{p})$, antigen (peptide), APC, antigen presenting cell; APGS, autoimmune polyglandular syndrome; $\mathrm{BB}$, Bio Breeding; $\mathrm{CD}$, cluster of differentiation; $\mathrm{Cy}-\mathrm{Ad}-\mathrm{Abs}$, adrenal cytoplasmic antibodies; D, diversity; DC, dendritic cell; DTH, delayed type hypersensitivity; EPM1, Unverricht-Lundborg type of progressive epilepsy; HLA, human leukocyte antigen; IDDM, insulin dependent diabetes mellitus; IFN, interferon; Ig, immunoglobulin; IIF, indirect immunofluorescence; IL, interleukin; J, joining; MHC, Major Histocompatibility Complex; MIF, migration inhibiting factor; NK, natural killer; NOD, Non Obese Diabetic; NU, athymic nude; OS, Obese Strain chicken; POF, premature ovarian failure; PTK, protein kinase; ROS, resistant ovary syndrome; SLE, systemic lupus erythematosis; $\mathrm{SmIg}$, surface membrane bound immunoglobulins; SSLP, single sequence length polymorphisms; St-C-Abs, steroid cell antibodies; TCR, T cell receptor; Th, T helper; TNF, tumor necrosis factor; $\mathrm{V}$, variable; $\mathrm{ZP}$,

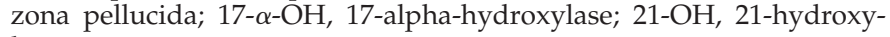
lase.
VII. Signs of Ovarian Autoimmunity in Patients with Idiopathic POF in the Absence of Adrenal Autoimmunity and/or Addison's Disease

A. Histology of the ovaries in patients with idiopathic POF in the absence of adrenal autoimmunity and/or Addison's disease

B. Autoantibodies in patients with idiopathic POF in the absence of adrenal autoimmunity and/or Addison's disease

C. Cellular immune abnormalities in patients with idiopathic POF in the absence of adrenal autoimmunity and/or Addison's disease

D. Conclusions

VIII. Animal Models of Autoimmune Oöphoritis

A. Immunization with crude ovarian antigens

B. Immunization with heterologous $\mathrm{ZP}$ antigens or purified ZP3 antigens

C. Neonatal thymectomy models

D. Transfer of normal T cells to athymic (nu/nu) mice

E. Conclusions

IX. Summary

\section{Introduction}

$\mathrm{T}$ HE most important function of the immune system is to discriminate between 'self' and 'nonself.' The self needs to be protected, whereas the nonself must be destroyed. In some pathological processes the recognition of self is lost and the immune system starts to attack self, leading to a so-called "autoimmune disease."

Currently, the distinction between self and nonself is considered to involve a series of complicated and multistage interactions between various cells of the immune system. There is currently accumulating evidence that some cases of premature ovarian failure $(\mathrm{POF})^{1}$ are due to a faulty recognition of self in the ovary by the immune system.

POF or premature menopause is a syndrome clinically defined by failure of the ovary before the age of $40 \mathrm{yr}$ (1). POF is a heterogeneous disorder with a multicausal pathogenesis, and chromosomal (2-9), genetic (4, 10-12), enzymatic (13-14), iatrogenic (15-20), or infectious (21-22) aberrations may all form the basis for the disappearance of ovarian follicles. These aberrations may influence the ovary at any stage of life, including the prepubertal, pubertal, or reproductive stages (23).

This review will primarily focus on the accumulating evidence of an abnormal self-recognition leading to ovarian autoimmunity in a proportion of patients with POF. This places 
some cases of POF in the group of autoimmune diseases that affect hormone-producing glands, the so-called "autoimmune endocrinopathies," such as thyroiditis, insulin-dependent diabetes mellitus (IDDM), and Addison's disease.

\section{Definition and Clinical Presentation of Premature Ovarian Failure (POF)}

Menopause (cessation of menses on the basis of ovarian failure) is in principle a physiological event. Women in western countries experience menopause at an average age of 50 yr (24-26). The number of primordial follicles decreases with age $(27,28)$, and the ultimate disappearance of primordial follicles in the ovaries is held responsible for the cessation of ovarian function in menopause. However, morphologically normal oocytes can be found in postmenopausal ovaries using electron microscopy (29), indicating that such disappearance cannot be the sole factor playing a role in the development of the menopausal state. It has, for instance, been hypothesized that the remaining follicles in perimenopausal women are less sensitive to high levels of gonadotropins (30).

POF was defined by de Moraes-Ruehsen and Jones in 1967 (1) as an unphysiological cessation of menses before the age of $40 \mathrm{yr}$ and after puberty (hence, in fact, secondary amenorrhea). Women with POF have a hypergonadotropic-hypoestrogenic hormone profile. By 1939, the endocrinological profiles of the syndrome had been recognized on the basis of elevated levels of urinary gonadotropins (31). The clinical picture of POF was first described in detail in 1950 by Atria (32). This author reported 20 young women under the age of $35 \mathrm{yr}$ with secondary amenorrhea, hot flushes, infertility, and an atrophic endometrium. In retrospect, these cases presumably were cases of POF, although at that time confirmatory gonadotropin assays were not routinely performed.

Patients with POF are mainly troubled by infertility due to the cessation of ovarian function. They have a typical menstrual history of normal age at menarche $(33,34)$ followed by regular periods. The disease thereafter presents either with oligomenorrhea or abrupt amenorrhea. Presently, amenorrhea due to POF is also seen after termination of oral contraception (35-37). A family history of POF is incidently obtained $(10-12,37)$. Fifty percent of patients with POF experience vasomotor symptoms, such as hot flushes and sweating boosts (37-39) due to the hypoestrogenic status. Other troubling symptoms are atrophy of the vagina and the urological tract, leading to vaginitis, dyspareunia, and cystitis.

The diagnosis of POF rests upon the clinical picture and the demonstration of elevated gonadotropin levels. The level of FSH is disproportionally higher than that of LH (40). Serum levels of FSH greater than 40 IU / liter are the hallmark of the diagnosis. Serum gonadotropin determinations should be repeated at least two or three times to be certain of the diagnosis because serum gonadotropin levels may wax and wane (41-43). POF presents itself not as an all-or-none phenomenon, and the precise timing of onset is often impossible to determine. The disease may have a fluctuating course, with high gonadotropin levels that later return to normal, and a later regain of ovulatory functions and even pregnancy
(44-46). Nelson et al. (47) examined 65 POF patients by weekly estradiol sampling and sonography. In $50 \%$ of the cases, follicular activity could be demonstrated, and $16 \%$ of cases regained ovulatory function. Follicle biopsies were carried out in six patients, and these showed luteinized Graafian follicles (47). Alper et al. (44). reported that 7.5\% (six of 80) patients were able to conceive after a diagnosis of POF.

The incidence of POF in a population under the age of $40 \mathrm{yr}$ is estimated to be $0.9 \%$ (48). The choice of $40 \mathrm{yr}$ as the age that separates premature from normal menopause is arbitrary. If one were to define abnormality as those values less or greater than $2 \mathrm{sD}$ from the mean age of menopause (where $\pm 95 \%$ of the observations of a normally distributed variable are found), then the age of 43 would be the most appropriate lower age limit for the natural cessation of menses.

Kinch et al. (49) were the first to identify two histopathological types of POF: the afollicular and the follicular form. In the afollicular form, there is a total depletion of ovarian follicles and hence a permanent loss of ovarian function. Such total depletion of ovarian follicles is mainly due to gonadal dysgenesis, mixed gonadoblastoma, and hermaphroditism [reviewed by Coulam (23)]. Genetic and chromosomal abnormalities are one of the most well known causes of germ cell maldevelopment and disappearance (2). Such an accelerated loss of oocytes is considered to be the cause of POF in individuals with a 47,XXX and 45,XO and 45,X0 mosaicism $(2,9)$. Lack of migration of sex cells or faulty differentiation of the gonadal ridges lead to streak ovaries or, in some cases, to POF, depending on the actual number of primordial follicles that result.

In the follicular form, follicular structures are still preserved and hence a possibility of either spontaneous or induced return of ovarian function exists. The follicular form can be subdivided into: 1) oöphoritis (inflammation of follicles); 2) ovaries with a few follicles present; and 3) ovaries in which numerous primordial follicles are present [the socalled resistant ovary syndrome (ROS)] (50).

Although the histological classification suggests a sharp division between the follicular and afollicular forms, there is evidence that some cases of POF that were originally of the follicular type may progress to an afollicular stage. This is particularly the case in blepharophimosis $(51,52)$, galactosemia (53), and in the animal models of autoimmune oöphoritis (see below).

Recent research suggests that ovarian autoimmunity is a possible cause of both afollicular and follicular forms of POF. This review will list the arguments, pro and con, to such a view. At first, however, a short introduction into the cells involved in the immune response and immunological principles of self- and non-self-recognition will be given. This information will provide the background necessary to understanding these arguments.

\section{Cells Involved in the Immune Response}

\section{A. Antigen presentation and antigen-presenting cells, in particular dendritic cells}

An immune response against nonself- and self-antigens is initiated by presentation of the antigen in a suitable form to 
$\mathrm{T}$ cells. Antigen can only be presented to T cells in the context of molecules of the major histocompatibility complex (MHC) (54). Hence, practically each nucleated cell of the body is able to present antigen, first by virtue of a constitutive MHC class I expression, and second by a de novo expression of MHC class II molecules on the surface of the cell, induced by f.i. interferon- $\gamma(\mathrm{IFN}-\gamma)$ and tumor necrosis factor- $\alpha$ (TNF- $\alpha$ ) exposition (55). Macrophages, B cells, and particularly dendritic cells (DC) are, however, the most efficient (professional) antigen-presenting cells (APC) due to a variety of factors, among which are the constitutive expression of MHC class II molecules, the expression of costimulatory and adhesion molecules, and other characteristics such as motility (56).

The genes encoding for both MHC class I and II molecules are members of the immunoglobulin supergene family. These genes in the human species are arranged on chromosome 6 [reviewed by Weetman (57)]. MHC class I genes encode for the human leukocyte antigens (HLA) A, B, and C. MHC class II genes encode the HLA DP, DQ, and DR antigens. The encoded HLA molecules are dimers and comprise an $\alpha$ - and $\beta$-chain (Fig. 1). The $\alpha$-chain of the MHC class I molecules is encoded in the MHC genes; the $\beta$-chain is termed $\beta 2$-microglobulin and is encoded on a separate chromosome.

The overall structures of the class I and II MHC molecules are comparable (58). The molecular confirmation of the chains forms a groove in which the antigenic peptide is presented. Thus the ability of antigenic peptides to be associated with class I or class II MHC molecules is governed by the actual molecular confirmation (tertiary structure) of the

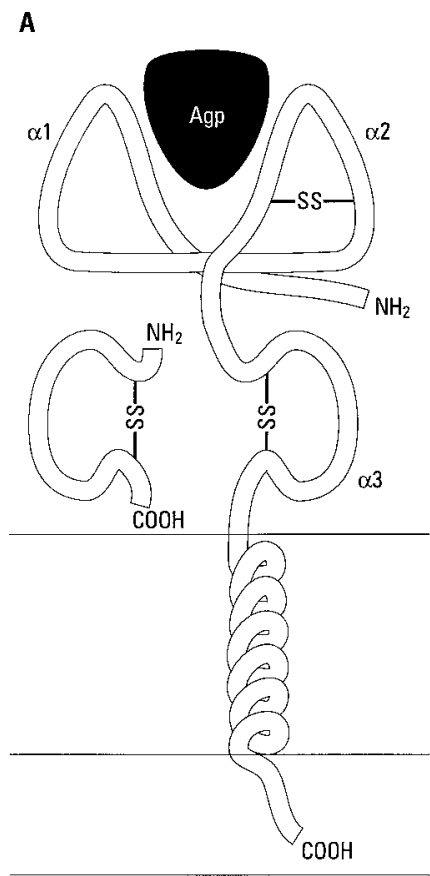

MHC class-I

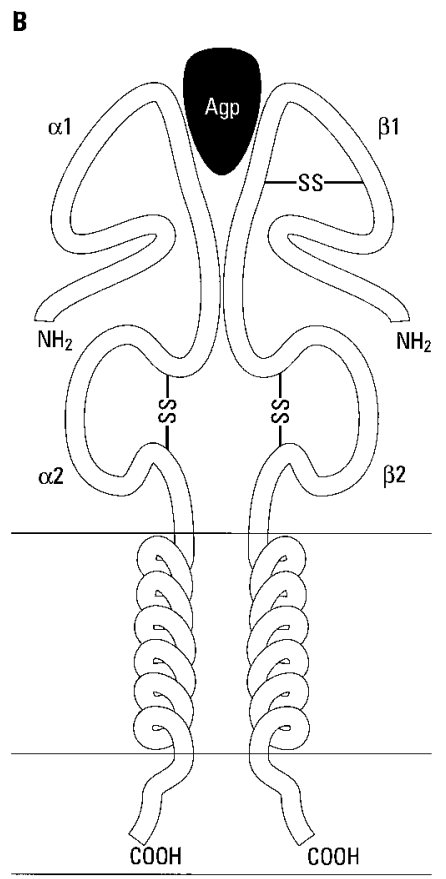

MHC class-II
FIG. 1. The structure of MHC-class I (A) and MHC-class II (B) molecules within the binding groove the antigenic peptides (Agp) [Reproduced with permission from the authors from: Benner R, van Dongen JJM, van Ewijk W, Haaijman J (eds) Medische Immunologie. Bunge, Utrecht, The Netherlands, 1996]. antigen-binding groove. It is therefore not surprising that organisms with a particular genetic makeup of MHC class I and II molecules have a special capacity to generate immune responses toward specific microbial and self-antigens.

An additional molecule, known as the invariant chain, is intimately involved in the biology of HLA class II molecules. The invariant chain is a membrane glycoprotein, encoded by a non-HLA gene on chromosome 5. The "invariant" designation stems from the observation that, in contrast to the extensive polymorphism of some class II $\alpha$ - and all class II $\beta$-chains, the invariant chain is nonpolymorphic. It forms a trimer with the class II $\alpha$ - and $\beta$-chains in the endoplasmic reticulum during biosynthesis of the MHC class II molecules and directs the trafficking of the trimer through the posttranslational machinery of the cell to the endosomal compartment (Fig. 2). Current evidence indicates that the invariant chain also prevents peptides from binding in the class II groove until the class II molecule is delivered to the endosome. The invariant chain then dissociates from the class II molecule, which can consequently bind antigenic peptides processed from exogenous antigens taken up by the APC and degraded in its lysosomal compartment (Fig. 2). The latter fuses with endosomes (59-61). The complex of the class II molecule with its bound peptide is then transported to the cell membrane (Fig. 2); however, the mechanism of transport

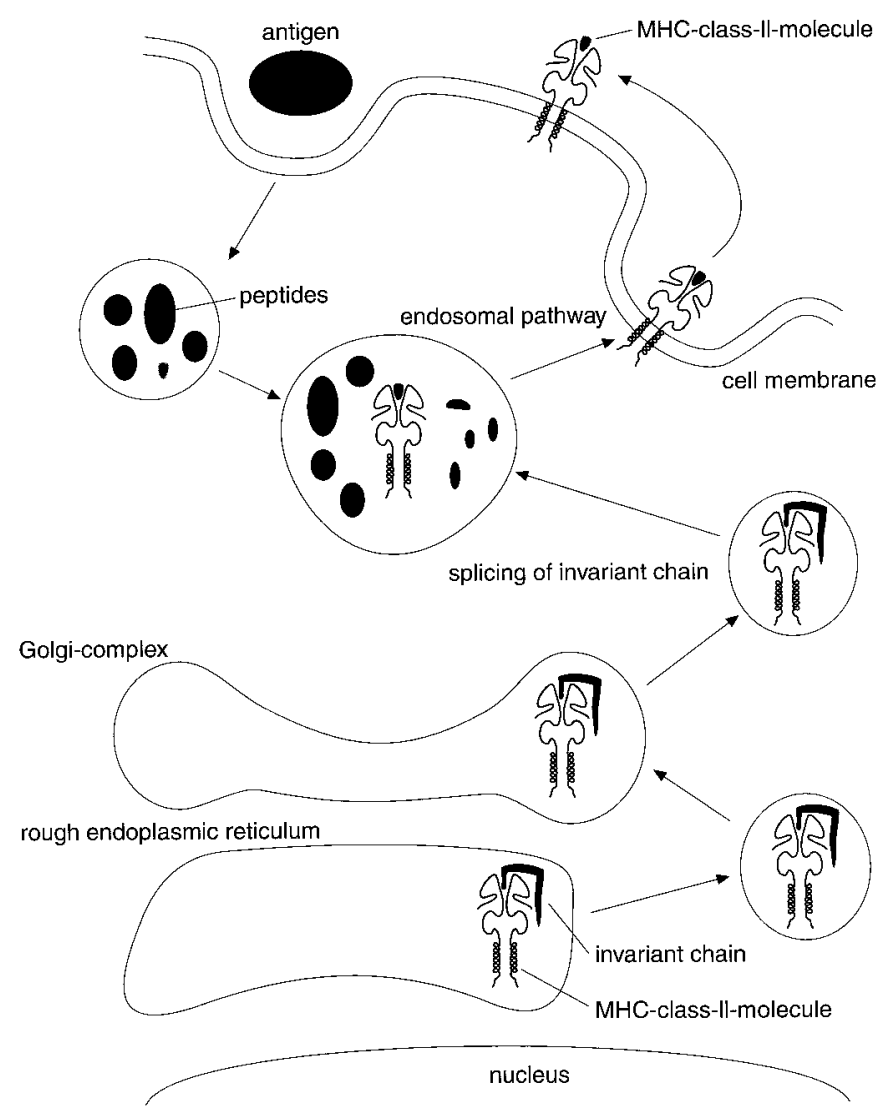

FIG. 2. The processing of exogenous antigens to result in the positioning of antigenic peptides in the groove of the MCH-class II molecule [Reproduced with permission from the authors from: Benner R, van Dongen JJM, van Ewijk W, Haaijman J (eds) Medische Immunologie. Bunge, Utrecht, The Netherlands, 1996]. 
is still unclear. Due to this intracellular pathway, exogenous antigens are mainly presented in association with MHC class II molecules (62). Peptides associated with MHC class II molecules can only be presented to $\mathrm{CD} 4^{+} \mathrm{T}$ cells (63), because the CD4 molecule is a special receptor for the MHC class II molecules (Fig. 3).

Endogenous antigens, e.g. viral antigens, are degraded by the low molecular mass polypeptide complex present in the cytoplasm (64). Peptides are then delivered to the MHC class I molecules in the lumen of the endoplasmic reticulum. After incorporation of the antigenic peptides into the groove and exposure of the MHC class I molecules on the cell surface, only $\mathrm{CD} 8^{+} \mathrm{T}$ cells are able to recognize such peptides, because the CD8 molecule is the special receptor for MHC class I molecules (Fig. 3). After recognition, $\mathrm{CD}^{+} \mathrm{T}$ cells are able to kill the cell presenting the endogenous antigen $(54,65)$. Neither class I nor class II MHC molecules can distinguish between self and nonself $(66,67)$. It must also be noted that the preferential association of exogenous antigens with MHC class II molecules, and endogenous antigens with MHC class $\mathrm{I}$, is not absolute $(62,68)$.

The complex of MHC molecule-antigenic peptide-T cell receptor (TCR) is insufficient for an adequate activation of
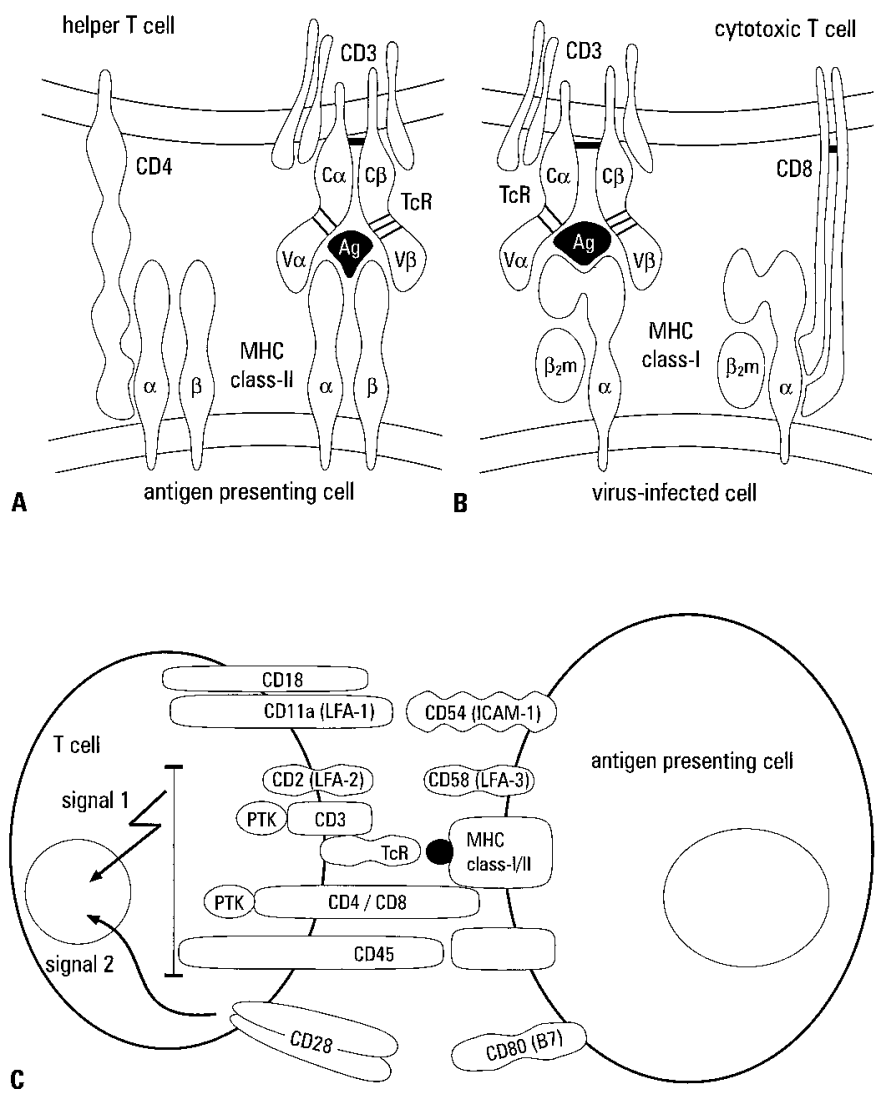

FIG. 3. The interactions between APC (including virus- infected cells) and $\mathrm{T}$ cells at the level of antigen-specific interactions, adhesion molecules, and costimulatory molecules. Panels A and B represent interactions between MHC molecules, the TCR, and CD4/CD8 molecules. Panel $\mathrm{C}$ depicts interactions between various adhesion molecules (ICAM-1/LFA1, LFA-3/LFA-2, CD45/unknown) providing signal 1 for $\mathrm{T}$ cell stimulation, and interactions of the costimulatory molecule CD80(B-7)/CD28, providing second signals (for abbreviations see Table 1). the $\mathrm{T}$ cell. For full activation, the interaction of other accessory molecules on APC with their ligands on T cells is needed, such as the interaction of adhesion molecules (6971). The binding produced by these adhesion molecules predominantly strengthens the interaction between the MHCantigenic peptide-TCR interaction, but also transduces signals that activate the T cell. Important adhesion molecules are leukocyte function antigen 1 (LFA-1), which interacts with intercellular adhesion molecule 1 (ICAM-1), and leukocyte function antigen 3 (LFA-3), which interacts with CD2 (70, 71) (Fig. 3). Inhibition in this process by monoclonal antibodies to either one of these adhesion molecules inhibits the activation and clonal expansion of T cells (69).

Apart from the adhesion molecule-ligand interaction, the interaction of so-called "costimulatory molecules" on APCs and $\mathrm{T}$ cells is essential for further $\mathrm{T}$ cell activation and $\mathrm{T}$ cell clonal expansion (Fig. 3). If these costimulatory signals are not provided, the result is T cell anergy [a state of specific nonresponsiveness of T cells (72)]. Costimulating signals are predominantly provided by the binding of the B7-1 (CD80) molecule on the APC $(73,74)$ to the CD28 molecule on the T cell. Additional binding of T-lymphocytic CTLA-4 (cytolytic T lymphocyte-associated antigen) to B7-2 (CD86) molecules on the APC also takes place but it occurs probably later in the process, because CTLA-4 is primarily seen on the T cells after activation (75).

DCs are unique APCs in that they are the only APCs that are able to effectively stimulate naive $\left(C D 45 \mathrm{RA}^{+}\right) \mathrm{T}$ cells (76-78). Recent investigations led to the idea that the DC population is heterogeneous with respect to ontogeny (79). It is certainly heterogeneous with respect to morphology, the expression of adhesion molecules (80-83), and in cytokine production. With regard to ontogeny, part of the DC populations is monocyte-derived and closely associated with macrophages, whereas other DCs may have a separate precursor [this subject was extensively reviewed by Kamperdijk et al. (84)]. DCs are found in virtually all tissues and organs of the body. The DC of the epidermis and dermis is known as the Langerhans cell. Langerhans cells contain the peculiar Birbeck granules that are not seen in DC in other organs, apart from the thymus. Langerhans cells of the skin and DC of the gut wall are considered as early (immature) stages in the differentiation of the cell, with a superb capacity to pick up antigens and to degrade these to antigenic peptides and place these peptides in the groove of the MHC molecules. Skin Langerhans cells and gut DCs have been shown to migrate into the afferent lymph as veiled cells to the skin- and gut-draining lymph nodes (Fig. 4). These cells can be seen as interdigitating cells in the $\mathrm{T}$ cell areas of these draining lymph nodes, and these stages of the DC are considered as mature stages of the cell with a superb capacity to stimulate $\mathrm{T}$ cells (85). It seems likely that DC from other organs, like the heart, kidney, and endocrine organs, may undergo similar migration and maturation.

Whereas macrophages are a clear source of cytokines such as interleukin-1 (IL-1), IL-6, and TNF- $\alpha$, DC have been shown to produce the mRNAs of these cytokines, without a noteworthy production of the actual products $(84,86,87)$. In general, DCs are regarded as poor producers of cytokines, and their excellent APC function lies probably in their mi- 


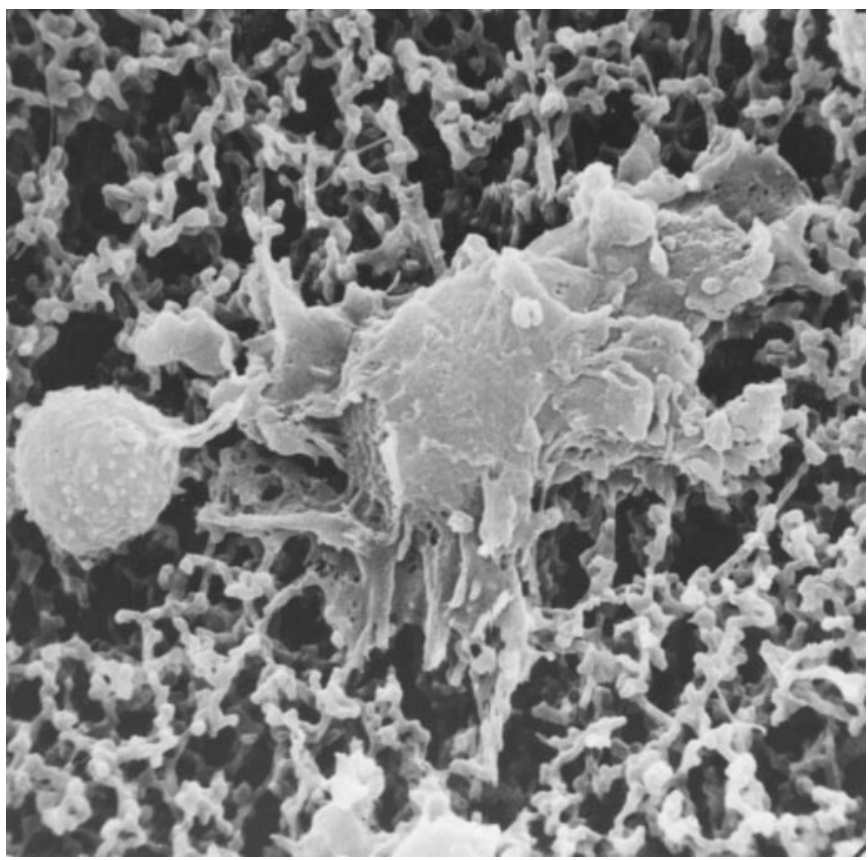

FIG. 4. A scanning electron microscopy photograph of a DC in lymph in contact with a lymphocyte $(5000 \times)(\mathrm{pig})$.

gratory capacity, their capability to form clusters with $\mathrm{T}$ cells via adhesion molecules $(88,89)$, and their high expression of costimulatory molecules such as B7-1 and B7-2 (CD80/CD86) (90).

It is as yet unresolved whether the DC needs other cytokine-producing accessory cells to guide the generated clonal expansion of naive $\mathrm{T}$ cells in a certain direction of development. IL-12 is known to be produced by macrophages, and this cytokine is able to push the development of $\mathrm{T}$ cells into $\mathrm{T}$ cells that predominantly produce IFN- $\gamma(91)$; however, IL-10 (also produced by macrophages) down-regulates such development $(92,93)$.

\section{B. $T$ cells}

The ability of the immune system to specifically recognize all varieties of possible antigens is based on the enormous diversity of the antigen-specific receptors present on the $\mathrm{T}$ cells (TCR) and the enormous diversity of the surface membrane-bound immunoglobulins (smIg-receptors) on the $\mathrm{B}$ cell (94-97). When the TCR fits with the antigenic peptide in the groove of the MHC molecule, lymphocyte activation and clonal expansion will be initiated (95-97) provided the sufficient adhesion molecule and costimulating signals are given. A specific TCR can bind only one form of an antigenic peptide, and this will consequently lead to cell division of this type of TCR-specific lymphocytes. This is referred to as clonal expansion.

The TCR is composed in the majority of cases of an $\alpha$ - and $\beta$-chain (96-98) or in a minority of cases of a $\gamma$ - and $\delta$-chain $(99-102)$. The various chains of the TCR are encoded by different gene segments: variable $(\mathrm{V})$, diversity $(\mathrm{D})$, joining $(\mathrm{J})$, and constant $(\mathrm{C})$ gene segments. The $\mathrm{V}, \mathrm{D}$, and $\mathrm{J}$ gene segments form a large repertoire. The enormous diversity of the TCR is produced by the recombination of the various V,
$\mathrm{D}$, and $\mathrm{J}$ genes from this large repertoire during $\mathrm{T}$ cell maturation $(103,104)$. Thus, the capacity to react with all possible antigenic peptides is genetically programmed and created by germ line rearrangements and somatic mutations. The TCR is noncovalently linked to a series of transmembrane proteins called the CD3 complex (Fig. 3) $(98,102,105,106)$. Both CD4 and CD8 molecules on the T cells act as coreceptors for the MHC class II and MHC class I molecules, respectively, during the interaction of the TCR with the peptide-MHC complex $(107,108)$. The entire CD3/TCR/MHC-II/CD4 complex or the entire CD3/TCR/MHC-I/CD8 complex is involved in signal transduction (Fig. 3).

The identification and classification of various $\mathrm{T}$ cells (Table 1) is based on the expression of the CD3 complex, the coexpression of either CD4 or CD8 molecules, and the composition of the TCR (genetic makeup of various $\mathrm{V}, \mathrm{D}$, and J genes).

Over the past few years it has become clear that the population of $\mathrm{CD}^{+} \mathrm{T}$ cells can functionally be divided into two subsets based on their profile of cytokine production (109, 110) (Fig. 5). One subset predominantly produces IFN- $\gamma$, but also IL-2; this is the so-called Th1 subset. The other subset, Th2, produces predominantly IL-4 and IL-5. The functional significance of these different cytokine production profiles is that they represent different $\mathrm{T}$ cell-regulatory actions. Th1 cells and their cytokine products stimulate macrophages and hence cell-mediated immunity and macrophage-mediated cellular destruction. Th2 cells and their cytokine products stimulate B cells and hence lead to the humoral immune response. It must be noted, however, that the Th1 and Th2 subtypes represent extremes. There are many $\mathrm{CD} 4^{+} \mathrm{T}$ cells clones with a cytokine production profile intermediate between Th1 and Th2 cells. The driving of $\mathrm{CD} 4^{+} \mathrm{T}$ cells (Tho cells, Fig. 5) into either the direction of Th1 or Th2 is guided in a complicated network by the cytokines IL-1, IL-12, IL-10, IFN- $\gamma$, IL-4, and products of arachidonic acid metabolism (91-93, 111-115).

\section{B cells}

$B$ cells are generally identified by means of the expression of SmIg-receptors on their cell surface or by the expression of B cell-specific molecules (Table 1). When the SmIg-receptor of a B cell recognizes the antigen against which it is directed, and when sufficient additional stimulatory signals are provided (see below), proliferation will occur. The generated B cells will thereafter differentiate into plasma cells that start to secrete immunoglobulins with a specificity similar to that of the earlier membrane-bound form of immunoglobulin.

When antigen-specific B cells and activated T cells recognize the same antigen or a peptide thereof, a so-called "cognate interaction" occurs (Fig. 6). The B cell uses its SmIg receptor for uptake and concentration of the antigen (116). The antigen is processed and the antigenic peptides are presented on the B cell surface in the groove of the MHC class II molecules to the antigen-specific T cell. When the cognate interaction activates the $\mathrm{T}$ cell to produce and release the cytokines IL-4 and IL-5 (Th2 pathway), the B cell is stimu- 
TABLE 1. CD markers, respectively, for T cells, B cells, monocytes/macrophages, dendritic cells and NK cells

\begin{tabular}{|c|c|c|}
\hline $\mathrm{CD}$ & Name & Function \\
\hline \multicolumn{3}{|l|}{$\mathrm{T}$ cells } \\
\hline CD2 & T11 antigen; LFA-2 & Receptor for $\mathrm{T}$ cell activation; ligand for LFA-3 \\
\hline CD3 & T3 antigen & Associated with TCR; signal transduction from TCR to cytoplasm \\
\hline CD4 & T4 antigen & Involved in MHC-class II restricted antigen recognition \\
\hline CD8 & T8 antigen & Involved in MHC-class I restricted antigen recognition \\
\hline CD11a & LFA-1 antigen & Adhesion molecule binds to ICAM-1 and ICAM-2 \\
\hline CD25 & Tac antigen & IL-2 receptor/activation T cells (B cells and macrophages) \\
\hline CD28 & Tp44 antigen & $\begin{array}{l}\text { Receptor for B7/BB-1 antigen on activated B cells/T cells } \\
\text { proliferation }\end{array}$ \\
\hline CD45 & LCA; T200 antigen & Function unknown, common leukocyte antigen \\
\hline CD45RO & Restricted LCA & Activated (memory) $\mathrm{T}$ cells \\
\hline CD45RA & Restricted LCA & Virgin T cells, monocytes \\
\hline \multicolumn{3}{|r|}{ 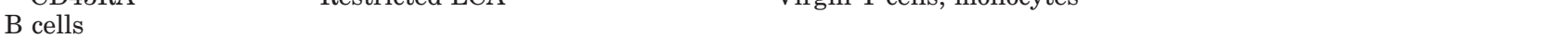 } \\
\hline CD5 & T1 antigen & Function in $\mathrm{T}$ cell proliferation, unknown function in B cells \\
\hline CD19 & Pan-B cell antigen & Function in B cell activation \\
\hline CD20 & $\mathrm{B}$ cell antigen & Function in $\mathrm{B}$ cell activation \\
\hline CD22 & $\mathrm{B}$ cell antigen & Function in B cell adhesion and activation \\
\hline SmIg & $\begin{array}{l}\text { Surface membrane } \\
\text { immunoglobulin }\end{array}$ & Binding molecule for antigens \\
\hline \multicolumn{3}{|c|}{ Monocytes/macrophages } \\
\hline CD11b,c & $\begin{array}{l}\text { Adhesion molecule on } \\
\text { monocytes/macrophages }\end{array}$ & $\begin{array}{l}\text { MAC-1 antigen, p150-95 antigen; associated with CD18 } \\
\text { antigen/adhesion molecule }\end{array}$ \\
\hline CD14 & Monocytic antigen & LPS receptor \\
\hline CD68 & Macrophage antigen & Function unknown \\
\hline \multicolumn{3}{|c|}{ Dendritic cells } \\
\hline CD1 & T6 antigen & MHC-like protein (antigen-presentation) \\
\hline CD83 & HB15 molecule & Function unknown \\
\hline S100 & & Intracellular growth factor \\
\hline \multicolumn{3}{|r|}{ Hilu acenturar growtir lactur } \\
\hline CD16 & Fc $\gamma R 111$ & Low affinity Fc receptor for IgG (also present on macrophages) \\
\hline CD56 & NCAM & Function unknown \\
\hline CD57 & $\begin{array}{l}\text { Human natural killer } \\
\text { cell antigen }\end{array}$ & Function unknown \\
\hline
\end{tabular}

CD, Cluster of differentiation; CR, complement receptor; ICAM, intercellular adhesion molecule; IgG, immunoglobulin G; LCA, leukocyte common antigen; LFA, leukocyte function antigen; LPS, lipopolysaccharide; MHC, major histocompatibility complex; NCAM, neural adhesion molecule; TCR, T cell receptor. [Derived from Ref. 176.]

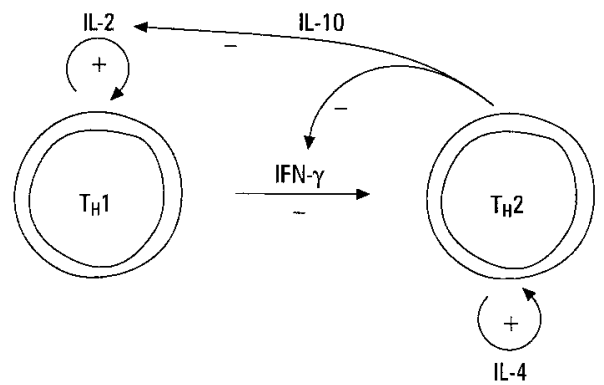

FIG. 5. The dichotomy in the action of $\mathrm{CD} 4^{+} \mathrm{T}$ cells in the Th1 and Th2 pathway and the action of various cytokines in the skewing of these pathways (+, activation; - , suppression).

lated to clonally expand and differentiate into a plasma cell to produce specific antibodies (117).

SmIg receptors on B cells show, like the TCR, a specificity toward antigens that is already programmed and created by germline gene rearrangement and somatic mutations $(103,104)$. An enormous variety of antibodies can thus be produced. Antibodies are composed of two Ig heavy chains and two Ig light chains held together by disulfide bonds (118). Antibodies play an important role in the neutralization of bacterial toxins and in the opsonization of microorganisms for phagocytosis.

Antibodies are produced in different isotypes (IgA, $\operatorname{IgG}$,

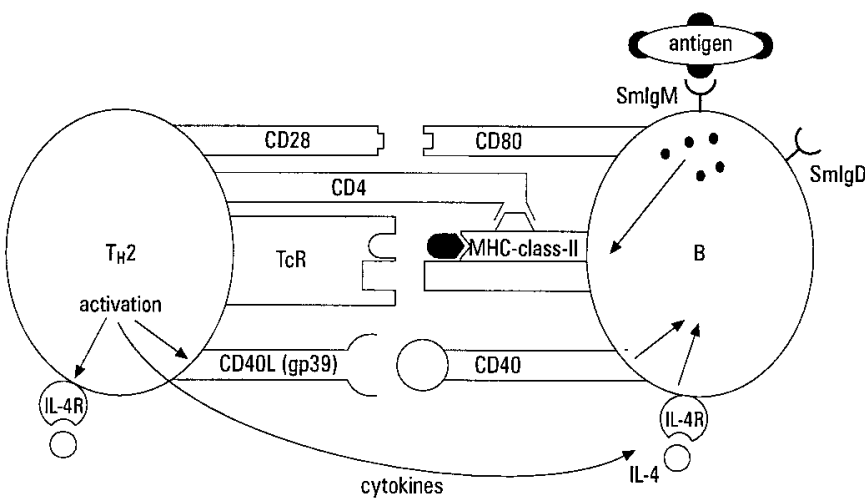

FIG. 6. The cognate interaction between Th2 cells and B cells to result in the specific stimulation of antigen-specific B cells. [Reproduced with permission from the authors from: Benner R, van Dongen JJM, van Ewijk W, Haaijman J (eds) Medische Immunologie. Bunge, Utrecht, The Netherlands, 1996.]

$\operatorname{IgM}, \operatorname{IgE}, \operatorname{IgD})$. The isotype is important in determining whether an antibody will fix complement (118). The majority of $\mathrm{B}$ cells in the peripheral blood express IgM and IgD on their cell surface, whereas a few express IgG or IgA. Secreted IgM antibodies are of low affinity and polyspecific. Secreted IgG and IgA antibodies are of high affinity and high specificity and are typical of secondary immune responses. The 
switch in immunoglobulin heavy chains from IgM and $\operatorname{IgD}$ to $\operatorname{IgG}$ or IgA is referred to as the isotype switch (119). This isotype switch is mediated by gene rearrangement in which the $\mathrm{V}$ region is coupled to another $\mathrm{C}$ region $(119,120)$. Autoantibodies of the IgG isotype are characteristic of certain pathological autoimmune reactions. To induce such antibodies, the help of autoantigen-specific Th2 cells is a prerequisite.

\section{Effector cells in immune responses}

Effector cells in immune responses are macrophages, natural killer (NK) cells, and cytotoxic $\mathrm{CD}^{+} \mathrm{T}$ cells. Macrophages form a heterogeneous population. Apart from immune regulation, certain subsets of macrophages act as important scavenging cells. They are able to endocytose and phagocytose microorganisms and cellular debris (121), as well as exerting cytotoxicity against microorganisms or tumor cells (122). The main function of macrophages is considered to be phagocytosis. Phagocytosis of microorganisms and cellular debris is greatly enhanced by opsonization of the material by specific antibodies, as well as the capability of the Th1 cytokine IFN- $\gamma$ to strongly activate the cytotoxic properties of macrophages, increasing their efficiency in killing the microorganism (123). Macrophages also play a role in wound healing $(124,125)$ and in the regulation of hemo- and lymphopoiesis $(126,127)$. Histologically classic macrophages are large cells that show lamellapodia and vacuoles and possess an irregular, indented nucleus (128). They stain for nonspecific esterase and acid phosphatase throughout the cytoplasm.

Though precursors of macrophages certainly reside in the monocyte pool the origin of all macrophages is not completely elucidated. A separate precursor in the bone marrow may exist for some subpopulations of macrophages (128). The monoblast and promonocyte remain in the bone marrow very briefly before entering the blood stream as monocytes (129). These latter cells migrate into the tissues where part of the cells mature and differentiate into various lines of macrophages such as the Kupffer cells, the osteoclasts, and the histiocytes. There is not one monoclonal antibody that recognizes all the lines and maturation stages of macrophages and that does not show a cross-reactivity with other hematopoietic cells. The lack of a common marker for all the subpopulations of macrophages is inherent to their functional heterogeneity. In human studies, macrophages are normally identified by specific CD markers (Table 1).

In exerting their various functions, macrophages are able to produce a variety of signaling molecules, such as the cytokines IL-1, IL-6, granulocyte-macrophage-colony-stimulating factor (GM-CSF), and TNF- $\alpha$ (128). Metabolites of arachidonic acid metabolism, nitric oxide and oxygen radicals, are also important products for the regulation of the immune response and the degradation of ingested material.

NK cells and $\mathrm{CD} 8^{+}$cytotoxic $\mathrm{T}$ cells are other important immune cells in the effector arm of the immune system. NK cells do not express conventional antigen receptors, such as the TCR or SmIg-receptors, and the genes for these receptors remain unrearranged $(130,131)$. They do express the receptor for the Fc part of the IgG molecule, the Fc $\gamma$ RIII (CD16) (132, 133). Other important molecules expressed by NK cells in- clude CD56, a neural adhesion antigen, and the $\beta$-chain of the IL-2 receptor. This allows resting NK cells to respond directly to IL-2 (134). The main function of NK cells is to provide nonspecific cytotoxic activity toward virally infected cells and tumor cells $(135,136)$. They do so by releasing perforin (pore forming) and serine proteases (137). NK cells, like macrophages, can also kill specifically if provided with an antibody. The process, known as antibody-dependent cellular cytotoxicity, occurs via binding of the antibody to the $\mathrm{FC}_{\mathrm{C}}$ receptor (CD16). The ontogeny of NK cells is only partially understood. Although NK cells express a number of membrane antigens in common with $\mathrm{T}$ cells and share functional properties with some $\mathrm{T}$ cell subsets, suggesting a common origin, NK cells are found in the fetus before the development of T cells or of the thymus. In addition, NK cells appear to develop normally in nude, athymic mice (135). Recent studies have indicated that NK cells can arise from triple negative $\left(\mathrm{CD}^{-} / \mathrm{CD} 4^{-} / \mathrm{CD} 8^{-}\right)$thymocyte precursors that are $\mathrm{CD} 56^{+}$but do not express CD34 or CD5 (138). It must also be noted that NK cells are not only considered as effector cells in the immune response, but also as regulator cells. They are sensitive to activation by Il-12, produce $\gamma$-IFN that activates the TH1 response, and are polyclonal activators of B cells (139).

Cytotoxic $\mathrm{T}$ lymphocytes consist of mature $\mathrm{T}$ cells that are usually, but not always, $\mathrm{CD} 8^{+}$. They exert cell contact-dependent cytotoxic functions through a perforin-dependent pathway (140). The cells also release the cytotoxic cytokine TNF. The perforin-dependent pathway is largely responsible for the T cell-dependent cytotoxic clearance of virus-infected cells and for rejection of tissue grafts and tumors (141).

\section{Tolerance to Self}

The main function of the immune system is to distinguish between self and nonself. In healthy individuals, reactivity toward self is nowadays considered to be a normal event that is controlled by several down-regulating mechanisms. Malfunction of these down-regulating mechanisms may result in an undesired excessive immune reaction toward self, i.e. an autoimmune disease. Among the best studied controlling mechanisms are the following: clonal deletion in the thymus, clonal anergy, and active immunosuppression by self-reactive subsets of $\mathrm{T}$ and B cells (142).

\section{A. Clonal deletion}

$\mathrm{T}$ cells mature in the thymus from prothymocytes to mature T cells. Because TCR rearrangement is random, selfreactive $\mathrm{T}$ cells are generated in this process. However, the vast majority of self-reactive $\mathrm{T}$ cells are deleted during further maturation in the thymus, the so-called "clonal deletion" $(143,144)$. DCs occurring in great numbers at the corticomedullary junction of the thymus express self-antigens and are responsible for this deletion. Clonal deletion depends upon recognition of the self-antigenic peptides by not fully matured $\mathrm{T}$ cells, which, upon the antigenic recognition signal, do not proliferate but go into apoptosis (145). A similar mechanism of deletion may exist for self-reactive B cells in 
the bone marrow (146). This mechanism is, however, not so well studied as clonal $\mathrm{T}$ cell deletion in the thymus.

Clonal deletion for $\mathrm{T}$ and $\mathrm{B}$ cells is, however, incomplete, and $\mathrm{T}$ and $\mathrm{B}$ cells with a specificity for autoantigenic peptides and autoantigens can easily be found in the circulation (147). This is partly explained by the fact that not all self-antigens are expressed in the thymus and bone marrow. Some selfantigens, such as ocular lens antigens, are sequestrated from the immune system. Other self-antigens, such as sperm-antigens, are only expressed during late fetal life or only in adult life. Some autoantigens probably never reach the thymus or bone marrow and are never expressed there. This particularly applies to cryptic epitopes. Cryptic epitopes are de novo expressed epitopes on self-antigens that are caused by changes in the antigen after, for instance, an inflammatory process.

\section{B. Clonal anergy}

When autoreactive B and T cells have escaped clonal deletion, a second control mechanism, namely the process of clonal anergy, should come into operation. This process takes place predominantly in the periphery (148-150). The induction of an immunologically anergic state of the $\mathrm{T}$ cell is supposed to be due to a lack of provision of sufficient second signals by APCs. Hence, when antigen is presented to T cells by nonprofessional APC, such as MHC class II-positive epithelial cells, clonal anergy will occur. Late in organ-specific autoimmune diseases (e.g. in autoimmune thyroiditis and IDDM) there is an aberrant expression of MHC class II molecules on the epithelial cells of the endocrine tissues (151). Initially, this aberrant expression of MHC class II molecules was interpreted as an impetus for the increased self-reactivity (152). However, this aberrant MHC class II expression late in organ-specific autoimmune disease can also be considered as a sign of induction of clonal anergy $(151,153)$.

\section{Active immunosuppression}

When clonal deletion and clonal anergy have failed, yet another down-regulating mechanism should come into operation, namely active immunosuppression exerted by socalled "suppressor" immune cells. These suppressor immune cells do not only include CD4 ${ }^{+}$and $\mathrm{CD}^{+}$T cells (154, $155)$, but also suppressor macrophages. The cells involved in immune suppression may be antigen-specific or non-antigen-specific. They may also operate in an idiotype-antiidiotype network (155). How active immune suppression is regulated remains unclear. Taken together, earlier and recent evidence suggests that in each individual a balance exists between autoreactive effector and suppressor immune cells. In the healthy state this balance tips over in favor of the suppressor forces, whereas in the autoimmune diseased state the balance is in favor of the self-reactive effector forces (see also later animal models of autoimmune oöphoritis).

\section{Balance between Th1 and Th2 pathways}

A recently developed theory approaches the problem of the control of self-reactivity from yet another angle. Endocrine autoimmune diseases with an ultimate failure of the target gland, such as IDDM, are predominantly caused by Th1-mediated pathways in which the endocrine cells are destroyed by $\gamma$-IFN-activated scavenger macrophages. The recently developed theory emphasizes the reciprocal relation between the Th1 and Th2 pathways $(109,156)$ and suggests that if the Th1 pathway is diverted into the Th2 pathway that the Th1-mediated autoimmune reactivity is dampened. In essence, tolerance to self is not restored, but the harmful autoimmune reaction is diverted to a less harmful one. There are indeed reports on cytokine treatments that are able to induce such a switch from Th1 to Th2 pathways, resulting in an amelioration of the endocrine autoimmune disease. Circulating antibodies, whose production is switched on by the stimulation of the Th2 cells, apparently contribute little to the damage of the target cells. It is known that endocrine autoantibodies may exist for years in the circulation before endocrine autoimmune disease develops $(157,158)$.

\section{Autoimmune Endocrine Disease: Developmental Stages and Genetic Predisposition}

Before presenting the pros and cons for considering POF as a possible endocrine autoimmune disease, it must be noted that there are similar failures of endocrine organs that are currently classified as autoimmune destructive diseases. These endocrine failures include hypothyroidism (thyroid failure), IDDM (failure of the islets of Langerhans), and Addison's disease (failure of the adrenal cortex). The pathogenesis of the failure of these endocrine tissues has mainly been studied in animal models of the spontaneous forms of these autoimmune endocrinopathies. The obvious reason for this approach is that in the patients, tissues, cells, and sera are difficult to obtain and only then in the progressed stages of the disease.

The animal models for autoimmune disease of the thyroid are the Obese Strain of chicken (OS chicken) (159), the Bio Breeding (BB) rat (160), and certain strains of the Non Obese Diabetic (NOD) mouse. The BB rat and NOD mouse also suffer from an autoimmune insulitis leading to IDDM. Animal models for spontaneous autoimmune adrenalitis and oöphoritis are lacking. Only manipulations of normal mice (immunization with crude adrenal and ovarian extracts, and thymectomy plus cyclosporin A treatment) will lead to autoimmune adrenalitis and/or oöphoritis (161). A word of caution is necessary when trying to extrapolate data obtained in the animal models to the human situation: the animal models clearly show exaggerated and extreme forms of thyroiditis and insulitis, which already differ between the models themselves (let alone from patients), indicating a heterogeneity of the disease process. Hence, general conclusions drawn on the basis of studies in one animal model should always be verified in other animal models and certainly in human patients.

The animal models of insulitis and thyroiditis indicate that the pathogenesis of the autoimmune failure of an endocrine gland is a multistep process, requiring several genetic and environmental abnormalities to come together before fullblown autoimmune thyroiditis and/or insulitis develops. The following phases in the disease process can be discerned 
(Fig. 7): 1) An initial phase of early accumulation of APC and accessory cells (DCs, subclasses of macrophages) in the endocrine tissue; 2) A later phase of an apparently uncontrolled production of autoreactive $\mathrm{CD} 4^{+}$and $\mathrm{CD} 8^{+} \mathrm{T}$ cells and of autoantibodies of the IgG class in the draining lymph nodes; 3) A last phase where the target endocrine tissue becomes susceptible for the autoimmune attack by the generated autoreactive $\mathrm{T}$ cells and autoantibodies; this finally results in the destruction of the glandular tissue.

In the thyroids of patients with Graves' disease or Hashimoto goiter, and in the thyroids and islets of the above described animal models, increased numbers of specific subsets of macrophages and MHC class II-positive DC have been described (162). In the animal models, an increase in the number of these cells in the future target glands and a local clustering of these cells with $\mathrm{T}$ cells are the first signs of the developing autoimmune reaction $(151,163)$. This local enhanced accumulation precedes the clonal expansion of T cells and $\mathrm{B}$ cells in the draining lymph nodes, the production of autoantibodies by these lymph nodes, and further signs and symptoms of the later autoimmune disease. Foreign antigens of viral or bacterial origin (164), or self-antigens altered by toxins and drugs (165), or an excessive metabolic activity of the endocrine tissue (166) have all been described as separate possible causes of the attraction of the DCs to the endocrine tissue, already indicating a heterogeneity in causal factors at the level of the initiation of an endocrine autoimmune disease.

The initial phase of glandular accumulation of macro-

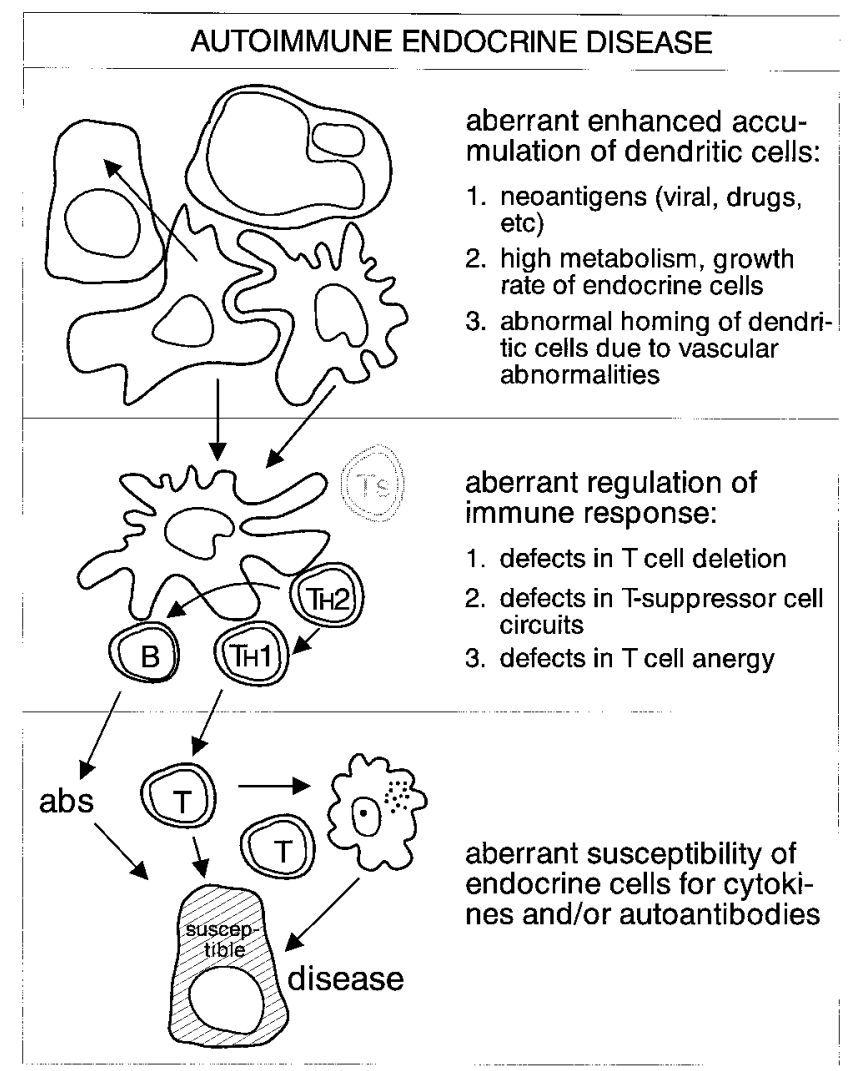

FIG. 7. The three developmental stages in an autoimmune endocrine disease. phages and APCs is followed by a phase of an apparently uncontrolled clonal expansion of autoreactive T cells and B cells and the production of autoantibodies in the draining lymph nodes. In both the BB rat and the NOD mouse, there are strong indications for a genetically linked systemic immunodysregulation leading to the local exaggerated production of T cells, B cells, and IgG antibodies to various selfantigens. This systemic immune abnormality is partly associated with the presence of particular MHC class I and class II haplotypes (see below) and apparently leads to abnormalities in the stimulation and differentiation of cells involved in tolerance induction, such as the APCs, macrophages, and/or T cells (169). Indeed, APCs of NOD mice (169) and BB rats (our unpublished observations) have defects in their capability to generate T suppressor cells. With regard to such abnormal maturation of immunoregulatory $\mathrm{T}$ cells, the BB rat is special in that it lacks a regulator population of T cells (the RT6 cells). BB rats also show a rapid thymic involution (170). The OS strain of chickens has inborn defects in its suppressor cell system (159). Whether there are similar inborn defects in immunoregulatory cells in the human that lead to an endocrine autoimmune disease needs to be established. There are, however, numerous reports on both numerical and functional deficits in the suppressor cell system of patients with thyroiditis and IDDM (171).

Deficits in immunoregulatory cells do not only exist on an inheritable, genetic basis. They can also be acquired by (fetal) viral infections. In chickens, Avian Leucosis Virus has proven to exert a detrimental effect on thymus and bursa development, which disturbs delicate immune regulatory systems, leading to thyroid autoimmunity (172). Whether similar viruses or retroviruses with an affinity for immune cells are operative in human endocrine autoimmune diseases has been speculated upon but has not yet been proven. Experiments to detect virions and/or retroviral antigens have not been conclusive in showing the involvement of infectious viruses in human endocrine autoimmune disease (172).

After the stage of the excessive generation of autoreactive $\mathrm{T}$ cells and IgG autoantibodies, yet another factor or factors, at least in the OS chicken, determine whether or not a full blown autoimmune disease will develop (173). A prerequisite for clinical thyroid failure in this bird is a susceptibility of the target, the thyrocyte, for an autoimmune attack by the generated autoreactive T cells and IgG autoantibodies. Experiments have shown that this susceptibility factor is genetically determined, and it has been speculated that this factor might be an abnormal susceptibility of the thyrocytes for the cytokines produced by the autoreactive immune cells after infiltration. Whether such susceptibility factors are also important in the other animal models and in human disease needs further investigation, although in the BB rat a high susceptibility of pancreatic islet cells for IL-1 has been established.

Population, family, and twin studies have clearly shown that genetic factors exert a significant influence on the predisposition for an autoimmune endocrine disease. It is also clear that environmental factors (diet, infections, etc) contribute to disease expression because concordance rates in monozygotic twins and inbred animals are often imperfect. Since endocrine autoimmunity can be transferred by lym- 
phocytes and bone marrow precursor cells into recipients, genes associated with the immune system have received prime attention. At present, convincing evidence does not exist for a relationship between the predisposition to an endocrine autoimmune disease and particular TCR haplotypes or polymorphisms, immunoglobulin allotypes and idiotypes, or cytokine genes (174). However, there is a clearly established genetic association with genes encoding for the MHC. In the BB rat this is the $\mathrm{Rt}^{1}$ haplotype (167), and in the NOD mouse the $\mathrm{H} 2 \mathrm{~g}^{7}$ haplotype (168). The human thyroid, islet, and adrenal autoimmune diseases are predominantly associated with HLA-DR3, DR4, and DR5 haplotypes (57). The MHC may affect predisposition to endocrine autoimmune disease by several mechanisms that are not mutually exclusive. Autoantigenic peptides of glandular autoantigens may combine more easily with these particular MHC molecules than with others. It is, however, also possible that the disease association with these MHC haplotypes is due to a specific MHC-controlled shaping of the $\mathrm{T}$ cell repertoire.

Regardless of the mechanisms, it is apparent that the MHC haplotype per se is insufficient for the development of an endocrine autoimmune disease, as shown by the fact that autoimmunity-associated HLA-DR haplotypes are also found in perfectly normal individuals. Also, the $\mathrm{H} 2 \mathrm{~g}^{7}$ haplotype of NOD mice in congenic strains does not lead to IDDM in these animals. The genetic analysis of endocrine autoimmune diseases evidently requires an approach other than detailed typing of the MHC encoding genes. Such an approach has been found in the study on microsatellites.

Microsatellites or single-sequence length polymorphisms (SSLPs) are repeat sequences [usually dinucleotides, e.g. $\left.(C A)_{n}\right]$ that exhibit high degrees of polymorphism both between individuals and in the number of repeats at a given chromosomal site. SSLPs are abundant $(>100.000)$ and are randomly dispersed throughout the mammalian genome, thereby providing an enormous pool from which to derive markers (175). Several thousand microsatellite markers have thus far been identified and mapped to the mouse/rat and human genomes, respectively. Specific SSLP loci can easily be defined by PCR using oligonucleotide primers specific for conserved sequences flanking the individual repeats, and length polymorphisms among individuals are identified by electrophoresis of the amplified products on agarose or polyacrylamide gels. Todd et al. (168) pioneered the use of microsatellites and other informative markers to define broadly the genes associated with diabetes in NOD mice. Scanning the entire genome of the NOD mouse, they obtained evidence of linkage with ten distinct loci, termed Idd-1 to -10, distributed on at least nine different chromosomes and affecting different immunopathological features (Table 2). With the exception of Idd-1, which is linked with the MHC locus on chromosome 17, no individual locus appears to be absolutely essential for disease onset.

In addition to susceptibility loci, microsatellite mapping studies in $\mathrm{F}_{2}$ crosses between NOD and a diabetes-free strain, as well as between NOD congenic strains expressing normal background alleles at specific Idd loci, have permitted the identification of several protective alleles that confer various degrees of resistance to diabetes. It can be predicted that similar diabetes resistance genes exist in diabetes-free humans with diabetogenic MHC haplotypes.

In human IDDM, previous intrafamilial association studies and limited chromosomal marker analyses have shown linkage to the MHC (IDDM1) on chromosome 6, and the insulin locus (IDDM2) on chromosome 11. Two recent studies using dense microsatellite maps $(\sim 300$ markers at an average spacing of $\sim 11$ centimorgans), reconfirmed the major importance of IDDM1, but provided limited, if any, support for IDDM2. Both studies also identified new susceptability loci (Table 2).

TABLE 2. Susceptibility loci and candidate genes for IDDM

\begin{tabular}{|c|c|c|c|}
\hline Chromosomal location & Locus designation & Candidate genes & Remarks \\
\hline $\begin{array}{l}\text { NOD mouse } \\
1 \\
3 \\
3 \\
4 \\
6 \\
7 \\
9 \\
11 \\
14 \\
17\end{array}$ & $\begin{array}{l}\text { Idd-5 } \\
\text { Idd-3 } \\
\text { Idd-10 } \\
\text { Idd-9 } \\
\text { Idd-6 } \\
\text { Idd-7 } \\
\text { Idd-2 } \\
\text { Idd-4 } \\
\text { Idd-8 } \\
\text { Idd-1 }\end{array}$ & $\begin{array}{l}\text { Bcg/Lch/Lty (Nramp) } \\
\text { IL-2 } \\
\text { Fcgr1, Csfm, Cd53 } \\
\text { Bphs } \\
\text { Nosi } \\
\text { MHC }\end{array}$ & $\begin{array}{l}\text { Linked to Orch-5 } \\
\text { Linked to Orch-3 } \\
\text { Linked to Orch-1 }\end{array}$ \\
\hline $\begin{array}{l}\text { Human IDDM } \\
2 \mathrm{q} \\
6 \mathrm{p} 21 \\
6 \mathrm{q} \\
8 \mathrm{p} \\
8 \mathrm{q} \\
10 \mathrm{q} \\
11 \mathrm{q} 13 \\
11 \mathrm{p} 15 \\
18 \mathrm{q}\end{array}$ & $\begin{array}{l}I D D M 1 \\
I D D M 5\end{array}$ & $\begin{array}{l}\text { GAD1 } \\
M H C \\
S O D 2 \\
\text { GAD2 } \\
I N S\end{array}$ & \\
\hline
\end{tabular}

Abbreviations: Bphs, Bordetella pertussis-induced histamine sensitization; Csfm, colony stimulating factor, macrophage; GAD1, glutamic acid decarboxylase 1; GAD2, glutamic acid decarboxylase 2; INS, insulin; Nosi, nitric oxide synthase; Nramp, natural resistance-associated macrophage protein; SOD2, superoxide dismutase 2. [Derived from Ref. 174.] 


\section{POF in Association with Adrenal Autoimmunity and/or Addison's Disease}

One of the first signs that autoimmunity could be responsible for a failure of ovarian function came from the observation that ovarian failure could precede the onset of Addison's disease by 8-14 yr (177).

Addison's disease is an uncommon disorder (10-20 per million) caused by a deficiency of adrenocortical hormones. The prevalence is highest in the fourth decade of life, and there is a marked female preponderance (2.5:1). The nature of idiopathic Addison's disease in the majority of patients in developed countries is now regarded as autoimmune (178), in contrast to the nature of the disease in developing countries, which is still mainly due to tuberculosis (179). Autoimmune Addison's disease seldom develops in isolation, and several other endocrine glands and organs are generally affected (180), leading to an autoimmune polyglandular syndrome (APGS). Two main forms of APGS can be clinically discerned. APGS type I mainly affects children and is characterized by the association of mucocutaneous candidiasis, hypoparathyroidism, and Addison's disease. Ovarian failure is often part of the syndrome (in approximately $60 \%$ of cases). APGS type 1 is also termed APECED (autoimmune polyendocrinopathy-candidosis-ectodermal dystrophy). APGS type II is characterized by adrenal failure in association with hypothyroidism. The latter mainly occurs in the fourth decade of life and has a female preponderance. In this syndrome only $25 \%$ of women have amenorrhea and $10 \%$ have a classic POF $(181,182)$.

With regard to POF, the literature indicates that $2-10 \%$ is associated with Addison's disease and/or adrenal autoimmunity (183).

\section{A. Antibodies in POF patients with adrenal autoimmunity and/or Addison's disease}

The discovery in the 1970s of autoantibodies to the adrenal cortex (adrenal cytoplasmatic antibodies, Cy-Ad-Abs) formed an important impetus for the studies on the autoimmune nature of idiopathic Addison's disease. Two varieties of adrenal antibodies were subsequently recognized in the sera of patients with Addison's disease using indirect immunofluorescence (IIF) and cryostat sections of human or monkey adrenal glands. One variety demonstrated reactivity with the three layers of the adrenal cortex only, whereas the other variety also reacted with cytoplasmic antigens of other steroid-producing cells present in the ovary, testis, and placenta $(184,185)$. This latter subvariety of adrenal cytoplasmic antibodies was called steroid-cell antibodies (St-C-Abs), and its reactivity could be absorbed by adrenal homogenates, thus confirming the cross-reactivity with the adrenal cytoplasmic antibodies (186). There is an absolute association between the presence of St-C-Ab and that of $\mathrm{Cy}-\mathrm{Ad}-\mathrm{Ab}$, the former being detectable only when the latter is also present. $\mathrm{St}-\mathrm{C}-\mathrm{Ab}$ are of the IgG type and bind within the ovary to the hilar cells, the cells of a developing follicle, such as theca and granulosa cells, and to the corpus luteum cells.

Almost all patients with a primary amenorrhea and Addison's disease have a detectable serum titer of St-C-Ab; 60\% of patients with a secondary amenorrhea and Addison's disease show these antibodies (Table 3). In the absence of clinically overt gonadal failure, St-C-Ab have been described in about $15-20 \%$ of patients with clinical or latent Addison's disease (181). In the follow-up of the St-C-Ab-positive addisonian patients, about $40 \%$ of females developed ovarian failure in a period of $10-15 \mathrm{yr}$, whereas in males the St-C-Abs did not herald gonadal failure (however, numbers of studied patients were small).

Heterogeneity exists between type I and type II APGS in relation to St-C-Ab (Table 3): $60-80 \%$ of patients with hypoparathyroidism and Addison's disease (type I APGS) and $25-40 \%$ of patients with type II APGS show these antibodies. In type 1 APGS without Addison's disease, $10 \%$ of patients show St-C-Abs. The high prevalence of St-C-Ab in patients with APGS type I probably explains the common association with gonadal failure seen in this group, and the appearance of the St-C-Abs in a female patient with APGS type I without adrenocortical or ovarian failure signals a high risk of their development $(185,187,188)$. The sensitivities/specificities / predictive values for St-C-Abs in females with type 1 APGS who initially had normal adrenocortical and ovarian function were 1.0/0.56/0.50 in predicting ovarian failure and $0.86 / 0.83 / 0.86$ for St-C-Abs in predicting adrenocortical failure (188).

The mere presence of an autoantibody in the serum of a patient is certainly not evidence for the pathogenic significance of the antibody; the autoantibody may also be the consequence of cellular destruction, such as is seen after the destruction of cardiac muscle cells in myocardial infarction, giving rise to anti-heart cell antibodies. It has been shown, however, that sera of patients with APGS type I and Addison's disease, positive for $\mathrm{Cy}-\mathrm{Ad}-\mathrm{Ab}$ and $\mathrm{St}-\mathrm{C}-\mathrm{Ab}$, are cytotoxic for cultured granulosa cells in the presence of complement, when high titers of these antibodies were demonstrated in nine of 23 cases (189). Complement-dependent cytotoxicity of the St-C-Abs might indeed be one of the mechanisms leading to destruction of steroid-producing cells in vivo and thus to ovarian failure.

In recent years, considerable progress has been made with regard to the identification of the target antigens of $\mathrm{Cy}$-AdAbs and possibly of St-C-Abs (190). It has been found that the adrenal cytochrome p450 enzyme 21 hydroxylase (which converts 17- $\alpha$-progesterone and progesterone into 11-deoxy-

TABLE 3. Prevalence of steroid-cell antibodies (St-C-Abs) in patients and controls

\begin{tabular}{lc}
\hline Ovarian failure & $<1 \%$ \\
Unselected infertility/amenorrhea & $5-10 \%$ \\
With autoimmune thyroid disease or, type 1 diabetes & $100 \%$ \\
With Addison's disease - primary amenorrhea & $60 \%$ \\
- secondary amenorrhea & \\
Addison's disease (without ovarian failure) & $10-20 \%$ \\
Isolated cases & $60-80 \%$ \\
With hypoparathyroidism/candidiasis (type I APGS) & $25-40 \%$ \\
With autoimmune thyroid disease (type II APGS) & $10 \%$ \\
Type I APGS, mucocutaneous candidiasis and & \\
hypoparathyroidism without Addison's disease & $<1 \%$ \\
Autoimmune thyroid disease or type 1 diabetes & $<1 \%$ \\
Healthy controls & \\
\hline
\end{tabular}

[Derived from Refs. 181, 186, 188, and own data.] 
cortisol and deoxycorticosterone), is the major autoantigen recognized by autoantibodies present in patients with Addison's disease $(191,192)$, either in the form of isolated adrenal failure or associated with hypothyroidism (type II APGS).

In type I APGS it is thought that autoantibodies are directed to other members of the cytochrome p450 enzyme family, namely to the p450 side-chain cleavage enzyme (p450-scc) and to 17- $\alpha$-hydroxylase $(17-\alpha-\mathrm{OH})(192-196)$, and to an ill-defined 51-kDa protein (197). However, there is some confusion on this subject, and not all investigators could confirm the presence of these autoantibodies in type 1 APGS [negative results: p450-scc $(198) ; 17-\alpha-\mathrm{OH}(198,199)]$. Of the steroidogenic p450 enzymes 21-hydroxylase is adrenal-specific, $17-\alpha-\mathrm{OH}$ is expressed in both adrenals and gonads, whereas p450-scc is present in adrenal, gonads, and placenta. The 51-kDa protein is present in islets, granulosa cells, and placenta.

Possible targets of the St-C-Abs in POF patients not be- longing to the groups of APGS I or II are thus 17- $\alpha-\mathrm{OH}$ and the p450-scc enzyme. However, in the one such patient with St-C-Abs, 17- $\alpha-\mathrm{OH}$ was not recognized (191). To the authors' knowledge, studies have not been published on correlations between the presence and activity of St-C-Abs and autoantibodies to either $17-\alpha-\mathrm{OH}$ or p450-scc in patients without APGS type 1 . Also, studies in which St-C-Ab activity would be adsorbed with the enzymes $17-\alpha-\mathrm{OH}$ or p450-scc would further illuminate the subject.

Apart from the autoantibodies, another strong argument for considering St-C-Ab-positive ovarian failure as an autoimmune disease is the histology of the ovarian lesions.

\section{B. Histology of the ovaries in patients with POF in combination with adrenal autoimmunity and/or Addison's disease}

Table 4 gives an overview of the reported histology of POF, including the reported cases of histologically confirmed oö-

TABLE 4. Histology of ovaries in relation to the antibody profile (adrenal/steroid cell antibody positive or negative) of the POF patients

\begin{tabular}{|c|c|c|c|c|c|c|c|c|c|}
\hline \multirow[t]{2}{*}{ Reference } & \multirow[t]{2}{*}{ Year } & \multirow[t]{2}{*}{ Cases } & \multicolumn{2}{|c|}{ Antibodies } & \multirow[t]{2}{*}{ Other antibodies/diseases } & \multicolumn{4}{|c|}{ Histology of cases } \\
\hline & & & Ovary & Adrenal & & Oöphoritis & $\begin{array}{c}\text { No } \\
\text { follicles }\end{array}$ & $\begin{array}{c}\text { Few } \\
\text { follicles }\end{array}$ & $\begin{array}{c}\text { Numerous } \\
\text { follicles }\end{array}$ \\
\hline \multicolumn{10}{|c|}{ A. With adrenal/steroid cell antibodies } \\
\hline Irvine et al. (185) & 1968 & 1 & + & + & Testis & + & & & \\
\hline Irvine (293) & 1980 & 5 & + & + & Addison's disease $5 \times$ & + & & & \\
\hline Coulam et al. (294) & 1981 & 1 & + & + & Thyroid abs ${ }^{+}$, gastric $\mathrm{abs}^{+}$ & + & & & \\
\hline Gloor and Horlimann (202) & 1984 & 1 & - & + & - & + & & & \\
\hline Rabinowe et al. (295) & 1986 & 1 & + & + & Addison's disease 3 yr later & + & & & \\
\hline Sedmak et al. (201) & 1987 & 1 & + & + & Thyroid $\mathrm{abs}^{+}$ & + & & & \\
\hline Anonymous (272) & 1987 & 1 & - & + & Thyroid abs ${ }^{+}$ & + & & & \\
\hline Wolfe and Stirling (296) & 1988 & 1 & + & + & Testis abs ${ }^{+}$ & + & & & \\
\hline Biscotti et al. (297) & 1989 & 1 & + & + & Testis abs ${ }^{+}$, gastric $\mathrm{abs}^{+}$ & + & & & \\
\hline \multirow{3}{*}{ Bannatyne et al. (200) } & 1990 & 1 & - & + & Thyroid abs ${ }^{+}$, Hashimoto's disease & + & & & \\
\hline & & 1 & - & + & Gastric $\mathrm{abs}^{+}, \mathrm{ANA}^{+}$ & + & & & \\
\hline & & 1 & + & + & - & + & & & \\
\hline \multirow[t]{2}{*}{ Lonsdale (298) } & 1991 & 1 & + & + & - & + & & & \\
\hline & & 1 & + & + & Thyroid abs ${ }^{+}$ & + & & & \\
\hline \multicolumn{10}{|c|}{ B. Without adrenal/steroid cell antibodies } \\
\hline \multirow[t]{2}{*}{ Russell et al. (299) } & 1982 & 1 & - & - & Granulomatous oöphoritis & + & & & \\
\hline & & 1 & n.a. & n.a. & n.a. & + & & & \\
\hline Friedman et al. (300) & 1987 & 1 & - & - & Thyroid abs ${ }^{+}$ & + & & & \\
\hline \multirow[t]{3}{*}{ Bannatyne et al. (200) } & 1990 & 1 & - & n.a. & n.a. & + & & & \\
\hline & & 1 & n.a. & n.a. & n.a. & + & & & \\
\hline & & 1 & - & - & - & + & & & \\
\hline Kinch et al. (49) & 1965 & 9 & n.a. & n.a. & n.a. & - & 6 & 1 & 2 \\
\hline Emperaire et al. (301) & 1970 & 7 & n.a. & n.a. & n.a. & - & 5 & 2 & 0 \\
\hline Zarate et al. (302) & 1970 & 7 & n.a. & n.a. & n.a. & - & 4 & 3 & 0 \\
\hline Sharf et al. (303) & 1972 & 10 & n.a. & n.a. & n.a. & - & 8 & 2 & 0 \\
\hline Starup and Sele (33) & 1973 & 15 & n.a. & n.a. & n.a. & - & 7 & 6 & 2 \\
\hline Falk (304) & 1977 & 3 & n.a. & n.a. & n.a. & - & 2 & 1 & 0 \\
\hline Duignan et al. (305) & 1978 & 8 & n.a. & n.a. & n.a. & - & 3 & 3 & 2 \\
\hline Board et al. (306) & 1979 & 8 & - & - & - & - & 2 & 4 & 2 \\
\hline Rebar et al. (41) & 1982 & 9 & n.a. & n.a. & Thyroiditis $3 \times$ & - & $\overline{5}$ & 4 & n.a. \\
\hline Russell et al. (299) & 1982 & 19 & - & - & - & - & 14 & 0 & 3 \\
\hline Menon et al. (307) & 1984 & 43 & n.a. & n.a. & n.a. & - & 27 & 16 & n.a. \\
\hline Aiman and Smentek (308) & 1985 & 14 & - & - & Crohn's disease $1 \times$, SLE $1 \times$, Graves' $1 \times$ & - & 9 & 2 & 5 \\
\hline Miyake et al. (244) & 1987 & 10 & - & - & IDDM $1 \times$, Thyroiditis $3 \times$ & - & 10 & 0 & 0 \\
\hline Rebar and Connolly (309) & 1990 & 12 & - & - & n.a. & - & 5 & 7 & n.a. \\
\hline Muechler et al. (219) & 1991 & 17 & - & - & ANA $^{+} 5 \times$, thyroid abs ${ }^{+} 2 \times$, testis abs ${ }^{+} 1 \times$ & - & 12 & 2 & 3 \\
\hline Total & & 215 & & & & $\begin{array}{r}24 \\
11 \%\end{array}$ & $\begin{array}{r}119 \\
55 \%\end{array}$ & $\begin{array}{r}53 \\
25 \%\end{array}$ & $\begin{array}{r}19 \\
9 \%\end{array}$ \\
\hline
\end{tabular}

abs, Antibodies; ANA, antinuclear antibody; IDDM, insulin-dependent diabetes mellitus; n.a., data not available; SLE, systemic lupus erythematosis. 
phoritis. All St-C-Ab-positive cases had lymphocytic oöphoritis, and of all lymphocytic oöphoritis cases reported, 78\% had St-C-Abs.

The macroscopic appearance of ovaries with lymphocytic oöphoritis was either cystic ( $50 \%$ of the cases), with smaller and larger cysts, or normal. The cyst formation is hypothesized to be due to the elevated levels of gonadotropins seen in these patients.

Concerning the pattern of microscopical infiltration, there is a marked similarity in the reported cases of lymphocytic oöphoritis in the different compartments of the ovary. In most cases the primordial follicles are unaffected, as well as the cortex of the ovary. It is the developing follicle that is predominantly infiltrated by mononuclear inflammatory cells. There is a clear pattern of increasing density of the infiltration with more mature follicles. Preantral follicles are surrounded by small rims of lymphocytes and plasma cells, whereas larger follicles have a progressively more dense infiltrate usually in the external and internal theca. The granulosa layer is usually spared in this process until luteinization of the degenerating follicle occurs. When cysts are present, they are luteinized with a marked leukocytic infiltration in the cyst wall and destruction of the lining cells. Atretic follicles and, when present, corpora lutea or corpora albicantia are infiltrated as well. This pattern of infiltration confirms that steroid-producing cells are a main target for the autoimmune attack. Mild infiltration might be seen in the medulla and hilar region of the ovaries. There is a perivascular and, surprisingly, a perineural infiltration in the hilus of the ovary (200).

Immunohistochemical analysis of the lymphocytic oöphoritis reveals that the inflammatory cells are mainly formed by $\mathrm{T}$ lymphocytes $\left(\mathrm{CD} 4^{+}\right.$and $\left.\mathrm{CD} 8^{+}\right)$with a few $\mathrm{B}$ cells, together with large numbers of plasma cells. Macrophages and NK cells can also be found. The plasma cells mainly secrete IgG, but also IgA or $\operatorname{IgM}(201,202)$, which probably indicates the local production of ovarian autoantibodies. That $\mathrm{T}$ cells are important in the ovarian destructive autoimmune reaction is mainly supported by data generated in the animal models of autoimmune lymphocytic oöphoritis (see below). The involvement of T cells also in human oöphoritis is suggested by a case report on a patient with autoimmune thyroiditis, adrenalitis, and POF in whom migration-inhibiting factor (MIF) production by peripheral $\mathrm{T}$ cells toward ovarian as well as testicular antigens was found (203). The MIF test is a sensitive antigen-specific test for the production of a cytokine, MIF, by peripheral blood T-lymphocytes when cultured in the presence of specific antigens. It must also be noted in this respect that granulosa cells of POF patients are more sensitive to $\gamma$-IFN, another T cell cytokine, than normal granulosa cells (55).

\section{Immunogenetic aspects of POF in association with adrenal autoimmunity and/or Addison's disease}

POF in association with adrenal autoimmunity and/or Addison's disease has not been analyzed for any separate immunogenetic susceptibility for the ovarian component. Autoimmune Addison's disease itself is associated with the haplotype HLA-B8/DR3, and in particular with the DR B1* 0301 allele (204).
Ovarian failure in the context of the APGS type I syndrome has been studied in more detail, and APGS type I does not display an HLA-B8/DR3 association. The only association of APGS type I and HLA haplotypes reported so far has been with HLA-A28 (205). Positive associations were found between the presence of HLA-A28 and hypoparathyroidism, adrenocortical failure, and IDDM within the APGS type I syndrome, but not with ovarian failure (205), which is important for this review. Interestingly, in the APGS type I patients with ovarian failure, HLA-A3 was more frequent while HLA-A9 was less frequent than in those with normal ovarian function (205). Using the microsatellite approach, the responsible gene for APGS type I has recently been mapped to the long arm of chromosome 21 (206). The UnverrichtLundborg type of progressive epilepsy EPM1 has been mapped to the same locus, viz 21q,22.3, and a candidate gene (EHOC-1) for APGS type I, but in particular for EPM1, has been identified as a gene coding for a protein with partial homologies to transmembrane proteins including sodium channel proteins (207).

\section{Conclusions}

If the above observations are correct, $\mathrm{POF}$ in the presence of Addison's disease and/or adrenal autoimmunity (only $2-10 \%$ of cases) is almost certainly an endocrine autoimmune disorder. This view is supported by: 1) the presence of autoantibodies to steroid-producing cells in the patients, 2) the characterization of shared autoantigens between adrenal and ovarian steroid-producing cells, and 3) the histological picture of ovaries of such cases (lymphoplasmacellular infiltrate particularly around steroid-producing cells).

The existence of an animal model for the autoimmune syndrome of adrenalitis/oöphoritis (see below) lends additional support to this view. It is clear that further genetic studies need to be performed to analyze whether there is a separate (immuno)genetic susceptibility for the ovarian component within the syndrome oöphoritis/adrenalitis.

\section{Signs of Ovarian Autoimmunity in Patients with Idiopathic POF in the Absence of Adrenal Autoimmunity and/or Addison's Disease}

A. Histology of the ovaries in patients with idiopathic POF in the absence of adrenal autoimmunity and/or Addison's disease

The histological picture of ovaries of POF patients without adrenal autoimmune disease is also summarized in Table 4. Approximately $60 \%$ of such cases of POF lack ovarian follicles, and in these cases fibrotic ovaries are found. In $40 \%$ of the cases, ovarian follicles are detectable and numbers vary from few to numerous. About $10 \%$ of such follicular cases have numerous follicles, and these latter cases probably belong to the ROS (208).

In 1969, Jones and de Moraes-Ruehsen (50) were the first to report on three patients with ROS; they called it the "Savage" syndrome after the name of their first patient. The syndrome is defined by the presence of numerous primordial follicles in the ovaries, a hypergonadotropic hypoestrogenic 
hormone profile, and a hyporeceptivity for high dosages of exogenous gonadotropins given for ovulation induction in patients with either primary $(49,50)$ or secondary amenorrhea $(51,209-216)$. ROS patients with a secondary amenorrhea clinically present as POF patients. The etiology of the syndrome is unknown, although several hypotheses have been put forward. These range from a lack of gonadotropin or estrogen receptors, postreceptor pathway disturbances, gonadotropins with inadequate bioactivity (217), serum factors modulating the action of FSH (218), and immune factors such as antibodies to gonadotropin receptors and thymus pathology, which is relevant for this review (216).

It is important to note that cases of lymphocytic oöphoritis can hardly be found in POF patients in the absence of adrenal autoimmunity / Addison's disease [six of 215 cases (Table 4)]. Muechler et al. (219), however, showed the presence of immunoglobulins in such non-oöphoritis-affected ovaries using direct immunofluorescence: in $50 \%$ of his cases he found vascular wall staining ( $\operatorname{IgA}, \operatorname{IgM}$, or $\operatorname{IgG})$, and in $30 \%$ the stroma and follicular cells were positive for immunoglobulins. Hypothetically, autoantibodies to the ovary may have been present in the ovary without reaching detectable levels in the serum or inducing a local inflammation. It must also be noted that Muechler's data have not been confirmed by others, and in fact the histology of POF in the absence of adrenal autoimmunity/Addison's disease is not helpful in supporting an immune pathogenesis of the disease. This also applies to the atrophy found in the majority of cases. This phenomenon may represent the endstage of an autoimmune process directed against ovarian structures (as is seen in animal models, see below), but it may also represent a final depletion of oocytes due to genetic or environmental factors.

More positive evidence of isolated POF representing an endocrine autoimmune disease is the reported higher than normal frequency of some other endocrine and neurological autoimmune diseases in POF patients (Table 5).

\section{B. Autoantibodies in patients with idiopathic POF in the absence of adrenal autoimmunity and/or Addison's disease}

1. Autoantibodies to endocrine organs (Table 5). Thyroid autoimmunity is the most prevalent $(14 \%)$ associated endocrine

TABLE 5. Antibody profile of patients with idiopathic POF without adrenal autoimmunity

\begin{tabular}{|c|c|c|c|c|c|c|c|}
\hline Reference & Year & $\begin{array}{l}\text { POF } \\
\text { cases }\end{array}$ & $\begin{array}{l}\text { Thyroid } \\
\text { abs/disease }\end{array}$ & $\begin{array}{l}\text { Parietal cell } \\
\text { abs/perniciosa }\end{array}$ & ICA/IDDM & $\mathrm{ACH}-\mathrm{R}-\mathrm{abs} / \mathrm{MG}$ & $\begin{array}{l}\text { Non-organ-specific abs/Systemic } \\
\text { autoimmune disease }\end{array}$ \\
\hline$\overline{\text { Behrman (310) }}$ & 1964 & 16 & 0 & 0 & 1 & 0 & \\
\hline Lundberg and Persson (291) & 1969 & 1 & 0 & 0 & 0 & 1 & \\
\hline Vallotton and Forbes (311) & 1969 & 2 & 0 & 2 & 0 & 0 & \\
\hline de Moraes-Ruehsen et al. (221) & 1972 & 16 & 6 & 4 & 0 & 0 & Idiopathic thrombocytopenic purpura $1 \times$ \\
\hline Ayala et al. (312) & 1979 & 2 & 2 & 0 & 0 & 0 & Sicca syndrome $2 \times$ \\
\hline Board et al. (306) & 1979 & 7 & 0 & 0 & 0 & 1 & \\
\hline Collen et al. (313) & 1979 & 1 & 0 & 0 & 0 & 0 & Vitiligo $1 \times$, rheumatoid arthritis $1 \times$ \\
\hline Williamson et al. (314) & 1980 & 2 & 1 & 0 & 0 & 2 & \\
\hline Coulam and Lufkin (315) & 1981 & 1 & 0 & 0 & 1 & 0 & Anti-ovarian abs (RIA) $1 \times$ \\
\hline Kuki et al. (212) & 1981 & 1 & 0 & 0 & 0 & 1 & \\
\hline Chiauzzi et al. (233) & 1982 & 2 & 0 & 0 & 0 & 2 & FSH-receptor abs $2 \times$ \\
\hline Russell et al. (299) & 1982 & 19 & 1 & 0 & 0 & 0 & $2 \times$ oöphoritis (Table 4 ) \\
\hline Rebar et al. (41) & 1982 & 26 & 3 & 0 & 0 & 0 & \\
\hline Bateman et al. (292) & 1983 & 1 & 0 & 0 & 0 & 1 & \\
\hline Coulam and Ryan (227) & 1985 & 71 & 5 & 0 & 0 & 1 & \\
\hline Tang and Faiman (234) & 1983 & 9 & 1 & 0 & 0 & 0 & $\begin{array}{l}\text { Rheumatoid arthritis } 1 \times \text {, vitiligo } 1 \times \text {, } \\
\text { Hashimoto } 1 \times\end{array}$ \\
\hline Aiman and Smentek (308) & 1985 & 32 & 3 & 0 & 1 & 0 & Crohn's disease $1 \times$, SLE $1 \times$ \\
\hline Alper and Garner (34) & 1985 & 32 & 11 & 0 & 0 & 0 & Vitiligo $1 \times$ \\
\hline Anonymous (271) & 1986 & 1 & 0 & 0 & 0 & 0 & SLE $1 \times$ \\
\hline Pekonen et al. (224) & 1986 & 10 & 0 & 0 & 0 & 0 & SLE $1 \times$ \\
\hline Friedman $(300)$ & 1987 & 1 & 1 & 0 & 0 & 0 & $1 \times$ oöphoritis (Table 4 ) \\
\hline Miyake et al. (244) & 1987 & 20 & 7 & 6 & 0 & 1 & $\mathrm{ANA}^{+} 8 \times$, thyroiditis $1 \times$ \\
\hline Ho et al. (245) & 1988 & 44 & 2 & 0 & 0 & 0 & $\mathrm{ANA}^{+} 1 \times$, Rheuma factor ${ }^{+} 1 \times$ \\
\hline Mignot et al. (316) & 1989 & 21 & 4 & 4 & 4 & 0 & $\begin{array}{l}\mathrm{ANA}^{+} 10 \times, \mathrm{nDNA}^{+} 6 \times \\
\quad \mathrm{Rheuma} \mathrm{factor}^{+} 9 \times, \mathrm{SM}^{+} 8 \times\end{array}$ \\
\hline Wolffenbuttel et al. (317) & 1987 & 1 & 1 & 0 & 0 & 0 & \\
\hline Rebar and Connolly (309) & 1990 & 115 & 12 & 0 & 0 & 0 & \\
\hline Luborsky et al. (229) & 1990 & 43 & 5 & n.a. & 1 & n.a. & Rheumatoid arthritis $1 \times$, SLE $1 \times$ \\
\hline van Weissenbruch et al. (235) & 1991 & 22 & 2 & 1 & 1 & 1 & Anti-pituitary $\mathrm{abs}^{+} 1 \times, \mathrm{ANA}^{+} 1 \times, \mathrm{SM} 2 \times$ \\
\hline Muechler et al. (219) & 1991 & 12 & 2 & 0 & 0 & 0 & $\mathrm{ANA}^{+} 5 \times$, testis $\mathrm{ab}^{+} 1 \times$ \\
\hline Belvisi et al. (318) & 1993 & 44 & 9 & 1 & 1 & 0 & $\mathrm{ANA}^{+} 4 \times, \mathrm{SM}^{+} 4 \times$ \\
\hline Nelson et al. (247) & 1992 & 23 & 5 & 4 & 0 & 0 & Rheumatoid arthritis $1 \times, \mathrm{ANA}^{+} 9 \times$ \\
\hline Tsirigotis and Craft (216) & 1994 & 1 & n.a. & n.a. & n.a. & 1 & \\
\hline Hoek et al. (248) & 1995 & 30 & 3 & 1 & 1 & 2 & $\mathrm{ANA}^{+} 2 \times, \mathrm{SM}^{+} 8 \times$ \\
\hline Total & & 629 & $\begin{array}{l}86 \\
13.8 \%\end{array}$ & $\begin{array}{c}23 \\
3.7 \%\end{array}$ & $\begin{array}{c}11 \\
1.7 \%\end{array}$ & $\begin{array}{c}14 \\
2.2 \%\end{array}$ & \\
\hline
\end{tabular}

abs, Antibodies; ANA, antinuclear antibodies; ACH-R-abs, acetylcholine receptor antibodies; ICA, islet cell antibodies; IDDM, insulindependent diabetes mellitus; MG, myasthenia gravis; n.a., data not available; SLE, systemic lupus erythematosus; SM, smooth muscle. [Derived from Ref. 183.] 
autoimmune abnormality reported in POF patients without an adrenal autoimmune involvement, followed by the presence of parietal cell antibodies (4\%), IDDM (2\%), and myasthenia gravis or positivity for acetylcholine receptor antibodies $(2 \%)$ (Table 5$)$. However, the general prevalence of positivity for thyroid antibodies and gastric parietal cell antibodies is only slightly above the prevalence found in normal populations. It is, however, remarkable that IDDM and myasthenia gravis, both relatively uncommon autoimmune diseases $(\ll 1 \%)$ are found relatively frequently in POF patients $(2-4 \%)$. Whether this high frequency is due to publication bias or to shared underlying immune dysregulating factors remains to be established. Systemic lupus erythematosus (SLE), antinuclear antibodies, and rheumatoid factors have also been reported with a higher frequency than normal in POF patients (Table 5). A relationship of POF with SLE is further strengthened by the finding of the presence of antiovarian antibodies in $84 \%$ of the cases of female SLE patients by Moncayo-Naveda et al. (220).

2. Ovarian autoantibodies. Strong support for an autoimmune character of isolated POF would be the presence of antibodies to ovarian structures in the serum of these patients. However, the major conclusion drawn from several investigations using IIF on gonadal tissue (animal or human) is that patients are negative for St-C-Abs $(186-188,221-225)$. It is worthwile to note that positive results regarding anti-ovarian antibodies have been obtained using assay methods other than routine IIF (see Table 6), but control subjects without idiopathic ovarian failure, postmenopausal women, and patients with iatrogenic ovarian failure were also found positive in these assays. It has become gradually clear from these studies that the presence and clinical activity of POF does not correlate with the presence of these antibodies in serum. Moreover, the results indicate that although antibodies to ovarian antigens are common in $\mathrm{POF}$, their pathogenic role remains questionable. They may be the consequence rather than the cause of the disease.

3. Receptor autoantibodies. Conflicting results have also been obtained in investigations on so-called "receptor antibodies." Receptor antibodies are directed to membrane receptors for hormones, and these antibodies can mimic the action of the hormone if they have a similar specificity and affinity for the receptor. Stimulating antibodies to the TSH receptor are the cause of the hyperthyroidism and goiter formation in patients with Graves' disease (230). On the other hand, receptor antibodies may also block the action of the corresponding hormone when they lack a stimulatory action but still bind to the receptor. Blocking receptor antibodies have been described as causal for myasthenia gravis (blocking antibodies to the acetylcholine receptor), some forms of insulin-resistant diabetes (blocking antibodies to the insulin receptor), and primary hypothyroidism [blocking antibodies to the TSH receptor (231)].

Thus, it is easily understood that receptors such as the LH and FSH receptors might become targets for blocking antibodies (Fig. 8), and such hypothetical antibodies could be a cause of ovarian failure. Experiments showing an interaction of antibodies of POF patients with FSH and LH receptor (function) have been described by various authors (Table 7). However, inconsistent data were generated with regard to the prevalence and the exact target of these antibodies; moreover, receptor antibodies were also found in patients with iatrogenic ovarian failure.

Recent data using cloned human LH and FSH receptors indicate that the human gonadotropin receptors are highly selective for their human ligands $(240,241)$, and this selectivity may also apply for the receptor antibodies. Therefore, Anasti et al. (237) used recombinant human gonadotropin receptors to detect a putative presence of immunoglobulins directed against the gonadotropins or their receptors in sera of patients with POF. The authors were unable to demonstrate the presence of blocking antibodies to LH or FSH receptors in any of the 38 POF patients studied.

In conclusion, the data on receptor antibodies in POF are not conclusive; antibodies to the LH and FSH receptors may exist, but their precise role and prevalence require further studies.

4. Antibodies to zona pellucida (ZP). Yet another specific set of ovarian antibodies playing a role in POF might be the antibodies to the ZP. The ZP is the acellular matrix that surrounds developing and ovulated oocytes and is also detectable in atretic follicles. Autoantibodies to $\mathrm{ZP}$ have been described as a cause of infertility in women. In women with unexplained infertility, these antibodies were seen in $5.6 \%$ of the cases, whereas in the normal controls positivity was seen in only $1.7 \%$ (242). ZP antibodies were thought to interfere with the sperm-oocyte interaction, thus inducing infertility. Animal models have demonstrated, however, that the ZP antibodies interfere with follicular development, and the presence of these antibodies in the experimental animals leads to follicular depletion and amenorrhea (see below). Grootenhuis et al. (unpublished observations), using an enzyme-linked immunosorbent assay, recently found three of 34 POF patients positive for IgG antibodies toward human recombinant ZP3. However, three of six postmenopausal

TABLE 6. Ovarian antibodies in patients with idiopathic POF

\begin{tabular}{|c|c|c|c|c|c|c|}
\hline Reference & Year & Assay system & Substrate & POF & Controls & Other diseases \\
\hline Coulam and Ryan (226) & 1979 & RIA & Human ovary homogenate & $14 / 15$ & $\begin{array}{c}1 / 10 \\
3 / 12 \text { p.m. }\end{array}$ & n.a. \\
\hline Coulam and Ryan (227) & 1985 & RIA & Human ovary homogenate & $30 / 110$ & n.a. & n.a. \\
\hline Damewood et al. (228) & 1986 & IIF & Human ovarian sections & $14 / 27$ & $\begin{array}{c}0 / 24 \\
1 / 22 \text { p.m. }\end{array}$ & $5 / 17$ other AID \\
\hline $\begin{array}{l}\text { Cameron et al. }(30) \\
\text { Luborsky et al. }(229)\end{array}$ & $\begin{array}{l}1988 \\
1990\end{array}$ & $\begin{array}{l}\text { IIF } \\
\text { ELISA }\end{array}$ & $\begin{array}{l}\text { Monkey ovarian sections } \\
\text { Human ovary/oocytes }\end{array}$ & $\begin{array}{c}\text { n.a. } \\
25 / 36\end{array}$ & $\begin{array}{l}1 / 13 \\
0 / 20\end{array}$ & $\begin{array}{l}4 / 10 \text { IOF } \\
7 / 9 \text { POF after pelvic surgery }\end{array}$ \\
\hline
\end{tabular}

IIF, Indirect immunofluorescence; ELISA, enzyme-linked immunosorbent assay; AID, autoimmune disease; p.m., postmenopausal women; n.a., not available; IOF, imminent ovarian failure. 


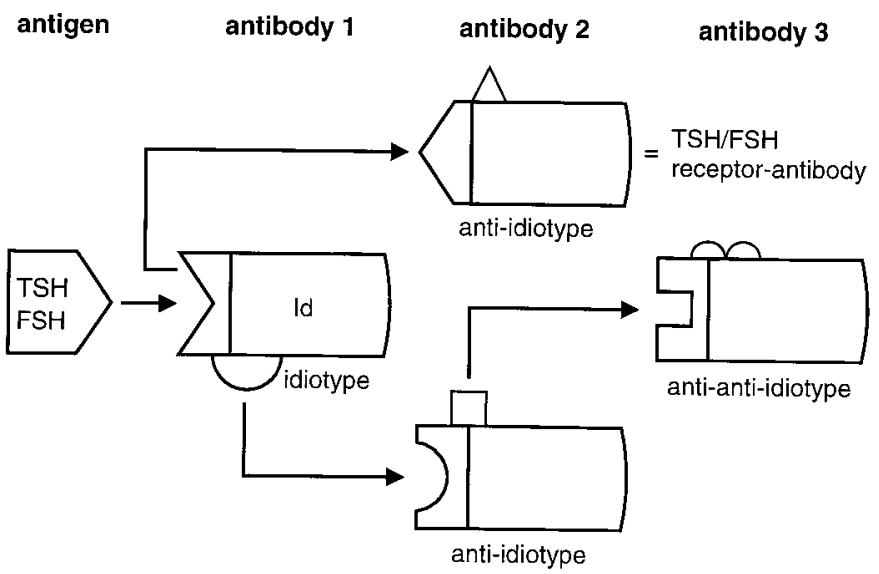

FIG. 8. An idiotype-antiidiotype cascade driven by a TSH or FSH molecule. As can be seen the second anti-idiotypic antibody group in the cascade is an antibody group that may contain antibodies reacting with the TSH or FSH receptor.

women were also positive, and it is thus likely that the antibodies toward ZP3 are the result of ovarian follicle damage, rather than their cause (in analogy to the other antiovarian antibodies described earlier).

\section{Cellular immune abnormalities in patients with idiopathic POF in the absence of adrenal autoimmunity and/or Addison's disease}

Recent literature (243) in the field of thyroid autoimmunity and IDDM indicates that immune cells, such as CD4 ${ }^{+}$Th1 lymphocytes, macrophages, and $\mathrm{CD}^{+} \mathrm{T}$ cytotoxic cells, are more important in the destruction of endocrine cells in endocrine autoimmunity as compared with the autoantibodies. So what is the evidence of such immune cell involvement in POF in the absence of adrenal autoimmunity and/or Addison's disease?

Table 8 gives an overview of studies on the numerical presence of various lymphocyte subsets present in the peripheral blood of patients with idiopathic POF. Although the data on the numbers of $\mathrm{CD}^{+}, \mathrm{CD}^{+}$, and $\mathrm{CD}^{+} \mathrm{T}$ cells vary between the reported studies, a consistent pattern of an increased number of activated T cells (as defined by MHC-class $\mathrm{II}^{+}$or IL-2R ${ }^{+}$) is evident in the majority of the studies. Similar increased numbers of activated peripheral blood $\mathrm{T}$ cells have been described in other autoimmune endocrinopathies, such as recent onset Graves' disease (249), IDDM (250), and Addison's disease (251). A word of caution is needed, however, because we recently observed that postmenopausal women may also show raised numbers of activated peripheral T cells (248). Estrogen substitution lowered the number of activated peripheral T cells in women with POF, although not to completely normal levels. Ho et al. (252) also demonstrated the importance of the estrogen status for the number of peripheral blood lymphocyte subsets. We therefore consider the hypergonadotropic hypoestrogenic hormone status present in POF patients and postmenopausal women as partly responsible for the raised numbers of activated blood $\mathrm{T}$ cells. Another more direct indication of the involvement of the $\mathrm{T}$ cell system in the pathogenesis of POF is given in the ex-

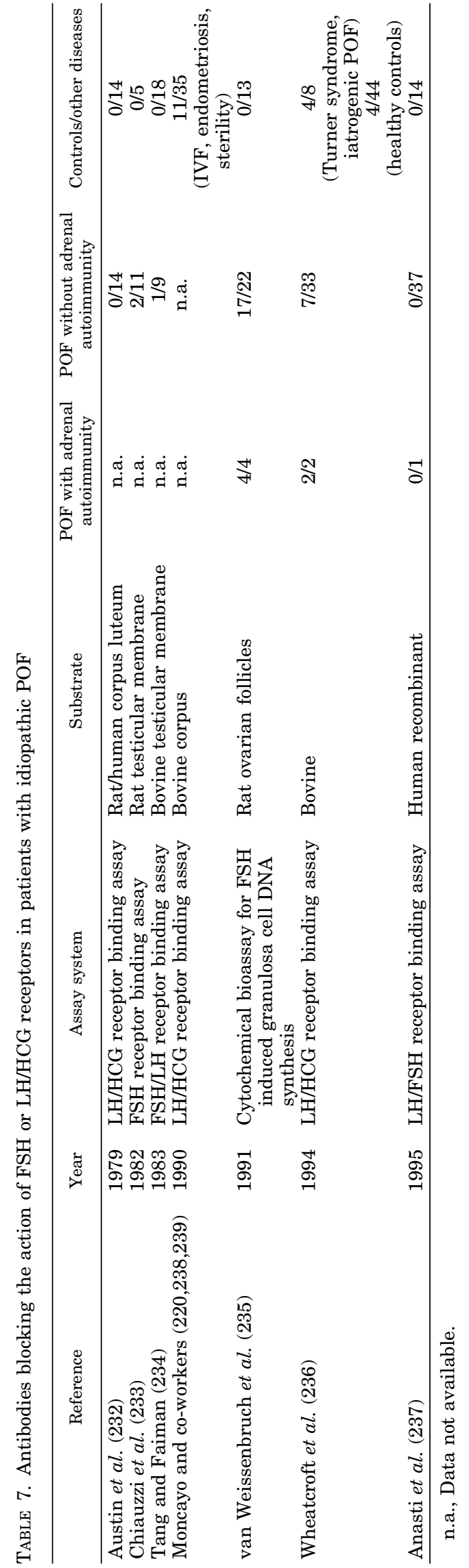


periments of Pekonen et al. (224). They detected in several cases of POF a positive MIF test toward gonadal antigens.

Taken together, the data on $\mathrm{T}$ cells in the literature may thus provide some support of the existence of a $\mathrm{T}$ cellular autoimmune response toward gonadal antigens in POF. However, again the question of consequence or cause must be addressed.

With regard to the peripheral B cell numbers, two of three studies reported an increase in the number of peripheral blood B cells $(245,248)$. One $(245)$ correlated the raised numbers of B cells to the presence of various auto-antibodies; we were unable to confirm this correlation (248). A similar increase in the number of peripheral B cells has been observed in other autoimmune endocrinopathies. It is therefore not unreasonable to interpret the raised numbers of peripheral blood B cells as a sign of activation of the humoral immune system crucial for autoantibody production, especially because estrogen substitution in POF women did not lower the raised number of peripheral B cells (248).

With regard to the number and activity of peripheral NK cells in POF, two reports have been published. We showed a decrease in the number of peripheral $\mathrm{CD}^{2} 6^{+} / \mathrm{CD} 16^{+} /$ $\mathrm{CD}^{-}$NK cells (248). Pekonen (224) showed decreased activity (lysis of K562 cells) of normal numbers of peripheral blood NK cells in $30 \%$ of POF women. A lowered activity of NK cells has also been described in patients with Graves' disease (253). Because NK cells play a role in immunoregulation, it has been hypothesized that these lowered numbers of NK cells or the lowered activity of the cells might influence $\mathrm{B}$ and $\mathrm{T}$ cells, resulting in the production of autoantibodies. On the other hand, it has been hypothesized that a decreased activity of the peripheral blood NK cells indicates a susceptibility for viral infection, thus increasing the chance for a viral oöphoritis. However, there is little clinical or histopathological evidence for a viral infection in POF.

An interesting new avenue is the study on the number and functions of monocytes and monocyte-derived DCs in endocrine autoimmune disease. In IDDM (254) and Graves' disease (255), an abnormal function of monocytes and monocyte-derived DCs (abnormal polarization, abnormal interaction with $\mathrm{T}$ cells) has been found by our group. Recently, studies were extended to POF, and similar disturbances were found that were not correctable by estrogen substitution (256).

The abnormalities in the function of peripheral monocytes, monocyte-derived DCs, T cells, and B cells in patients with POF seem to be part of a more complex cell-mediated immune abnormality, including defects in the delayed type hypersensitivity (DTH) reactivity to Candida antigen (256) and the MIF production of peripheral $\mathrm{T}$ cells toward this commensal antigen (246). Although we do not understand the clinical significance of these general defects and abnormalities in cell-mediated immunity in POF patients (patients did not show recurrent infections), they might be related to an immunodysregulation leading to endocrine autoimmunity. It must be noted in this respect that patients with chronic mucocutaneous candidiasis (part of the APGS type I) and patients with recurrent vaginal candidiasis (who do show DTH abnormalities to Candida) also show a raised incidence of autoantibodies toward ovarian antigens (257). Whether the APGS type 1 syndrome (where there is a connection between candidiasis and oöphoritis) represents the extreme of a spectrum of disorders combining T cellular deficiencies with ovarian autoimmunity requires further investigation.

\section{Conclusions}

In conclusion, there is some, albeit debatable, evidence that some cases of idiopathic POF in the absence of Addison's disease/adrenal autoimmunity may belong to the group of endocrine autoimmune diseases.

The positive evidence is formed by the fact that these cases of POF show similar cellular immune abnormalities to other endocrine autoimmune diseases such as IDDM, Graves' disease, and Addison's disease. These cellular immune abnormalities include abnormalities in the numbers and/or function of peripheral monocytes, monocyte-derived DC, and subsets of $\mathrm{T}$ cells and B cells. Another point of positive evidence might be the more than normal association of POF with IDDM and myasthenia gravis. However, data need to be confirmed and their relevance investigated. Moreover, data on anti-ovarian antibodies and anti-receptor antibodies are not conclusive, because these antibodies, although found by the majority of authors, might be the consequence rather than the cause of the disease. Another point of doubt is that the histology of POF in the absence of Addison's disease/ adrenal autoimmunity hardly shows oöphoritis $(<3 \%)$.

With regard to immunogenetic studies, one report (258) gives support for a concept that POF belongs to the endocrine autoimmune disorders: POF was associated with HLA-DR3 (258). This study, however, involved only 22 POF patients without adrenal autoimmunity. It must be noted that others were unable to confirm the association in later studies, using larger groups of POF patients of whom only a neglectable number had associated Addison's disease $(259,260)$.

\section{Animal Models of Autoimmune Oöphoritis}

Animal models can be helpful in elucidating the question: "Which form of POF is autoimmune in character?" Various models have been developed, and ovarian failure due to autoimmune destruction of the ovaries can be induced in animals using the following approaches:

A. Immunization with crude ovarian antigens.

B. Immunization with well defined ovarian antigens, such as ZP3, or peptides thereof.

C. Neonatal thymectomy in certain strains of mice.

D. Transfer of normal T cells into syngeneic athymic nude (nu/nu) mice.

These four approaches will be described in detail in this review. Other approaches (variants of C. and D.) are the neonatal treatment of mice with cyclosporin A (261), engrafting of fetal rat thymic grafts to $\mathrm{nu} / \mathrm{nu}$ mice (262), transplantation of neonatal thymic grafts to nu/nu mice (263), and transfer of normal neonatal spleen cells, neonatal thymocytes, and adult thymocytes to syngeneic nu/nu recipients (264). 
TABLE 8. Peripheral blood lymphocyte subsets in patients with idiopathic POF

\begin{tabular}{|c|c|c|c|c|c|c|c|c|c|c|c|}
\hline Reference & Year & $\begin{array}{l}\text { Total POF } \\
\text { cases }\end{array}$ & $\begin{array}{c}\text { POF }+ \\
\text { adrenal abs }\end{array}$ & $\mathrm{CD} 3 / \mathrm{CD} 2$ & $\mathrm{CD} 4$ & CD8 & $\begin{array}{c}\text { ratio } \\
\text { CD4/CD8 }\end{array}$ & $\begin{array}{l}\text { HLA-DR }^{+} \\
\text {T-cells }\end{array}$ & B-cells & NK-cells & Other \\
\hline Pekonen et al. (224) & 1986 & 18 & 2 & n.a. & n.a. & n.a. & n.a. & n.a. & n.a. & $\mathrm{N}$ & $\begin{array}{l}\text { NK cell activity }< \\
\text { MIF production } \\
\text { ovarian antigen }>\end{array}$ \\
\hline Miyake et al. (244) & 1987 & 19 & 0 & $\mathrm{~N}$ & $\mathrm{~N}$ & $\mathrm{~N}$ & $>$ & $>$ & n.a. & n.a. & Leu- $12^{+} \mathrm{B}$ cells $>$ \\
\hline Ho et al. (245) & 1988 & 45 & 1 & $>$ & $>$ & $>>$ & $<$ & n.a. & $>$ & n.a. & \\
\hline Rabinowe et al. (223) & 1989 & 23 & 2 & $\mathrm{~N}$ & $\mathrm{~N}$ & $\mathrm{~N}$ & $\mathrm{~N}$ & $>$ & n.a. & n.a. & $\mathrm{CD}^{+} \mathrm{T}$ cells $>$ \\
\hline Mignot et al. (246) & 1989 & 23 & 3 & $\mathrm{~N}$ & $>$ & $\mathrm{N}$ & $>$ & n.a. & $\mathrm{N}$ & n.a. & $\begin{array}{l}\text { MIF response } \\
\text { microbial antigens }<\end{array}$ \\
\hline Nelson et al. (247) & 1992 & 24 & 1 & n.a. & n.a. & n.a. & n.a. & $>$ & n.a. & n.a. & $\begin{array}{l}\text { IL-2 receptor }{ }^{+} \\
\text {T cells }>\end{array}$ \\
\hline Hoek et al. (248) & 1995 & 30 & 0 & $\mathrm{~N}$ & $\mathrm{~N}$ & $\mathrm{~N}$ & $\mathrm{~N}$ & $>$ & $>$ & $<$ & DTH candida $<$ \\
\hline
\end{tabular}

abs, Autoantibodies; DTH, delayed hypersensitivity skin test; MIF, migration inhibiting factor; N, normal; n.a., data not available; NK, natural killer; >, increased; <, decreased.

\section{A. Immunization with crude ovarian antigens}

Experimental autoimmune oöphoritis can be induced in animals, such as the rat and the BALB/c mouse, using immunization with bovine or rat ovarian extracts in complete Freund's adjuvant (265-267). The immunization establishes an autoimmune allergic oöphoritis as early as day 14 after immunization, with infiltration of the ovaries by immune cells. The autoimmune nature of the oöphoritis is underlined by a positive DTH reaction toward the injected ovarian antigens by day 14, illustrating the existence of a cell-mediated immune reaction toward the ovarian antigens. The appearance of germinal centers in the thymus and increased T cell activity and B cell stimulation in the spleen indicates that this experimental oöphoritis involves both T and B cells (267). The experimental autoimmune oöphoritis could also be induced by passive transfer of peripheral blood lymphocytes, spleen cells, and enriched $\mathrm{T}$ and B cell suspensions from ovarian antigen-immunized rats to naive recipients, indicating that $\mathrm{T}$ cells and $\mathrm{B}$ cells are important in the pathogenesis of the disease.

Anti-ovarian antibodies in the serum of the affected animals were not detectable before day 28 (265). The reproductive capacity of the rats, measured by litter size, could be correlated to the titer of the anti-ovarian antibodies. Moreover, passive immunization of rats with rabbit anti-rat ovarian serum resulted in a temporary dose-dependent reduction in litter size (268), indicating a role of the antibodies in the pathogenesis of the disorder. The antibodies produced in this experimental oöphoritis animal model are thought to interfere with ZP antigens inhibiting fertilization, and/or to disturb ovulation (269).

Histological examination of the ovarian tissue at day 14 after immunization showed characteristic perivenous accumulations of lymphocytes and macrophages as well as plasma cells $(265,266)$. The infiltrate was found beneath the tunica albuginea and in the interfollicular tissue, as well as in the granulosa layer of follicles. Occasionally, cell infiltrates were found in the external theca. The large secondary follicles and corpora lutea seemed unaffected, in contrast to the primordial and small secondary follicles. While the number of follicles and corpora lutea were decreased, the number of atretic follicles was increased. It is evident, in comparing the histology of this experimental oöphoritis rat model to the known cases of human autoimmune oöphoritis, that there are major differences. In human autoimmune oöphoritis, the main targets are the steroid-producing cells of the theca of maturing follicles and the corpus luteum, and not the interfollicular space and the secondary and primordial follicles such as seen in this animal model. This implies that the model may have only limited value in the study of human autoimmune oöphoritis and POF.

\section{B. Immunization with heterologous $Z P$ antigens or purified ZP3 antigens}

Immunization of New Zealand white rabbits with heterologous ZP antigens shows an induction of ovarian failure due to follicle depletion. Immunization experiments with porcine $\mathrm{ZP}$ in rabbits showed the development of $\mathrm{ZP}$ antibodies in the immunized animals. It was demonstrated that rabbits actively immunized with $\mathrm{ZP}$ proteins ceased to ovulate in response to hCG administration (269). The immunization of the rabbits induced a marked reduction in follicles and an atretic appearance of primary follicles. Growing follicles disappeared completely by 30 weeks post immunization. The reduction in number of normal follicles was accompanied by a striking increase in the number of oocytefree cell clusters. An oöphoritis such as that seen in the immunization experiments with crude ovarian extracts was not detected (270).

The alteration in ovarian function and histology in the rabbits could be correlated with the presence of serum antibodies to ZP glycoproteins. These studies and the histological pictures indicate first that the antibodies to $\mathrm{ZP}$ alter ovarian function and histology by interfering with cells during the stage of follicle differentiation at which ZP proteins are being synthesized (270), and second that the model might be of relevance in the study of human POF in the absence of adrenal autoimmunity. It has been hypothesized that ROS or premature depletion of ovarian follicles might represent the human counterpart of this animal model. However, Starup and Sele (33) showed that in the ovaries of ROS patients there was a normal ultrastructural appearance of the early follicles and no "oocyt-empty" follicle remnants, such as described by Skinner et al. (270) in the rabbit model. On the other hand, two cases of ROS have been reported in whom hyalinization of preantral follicles was described $(271,272)$.

The proteins of the $\mathrm{ZP}$ are conserved among mammals 
(273). ZP3 is a major ZP glycoprotein that functions as a sperm receptor (274), and mouse and human ZP3 proteins are $67 \%$ identical. It has been shown that a 15 -amino-acid peptide of ZP3 was able to induce oöphoritis in (C57BL/ $6 \times \mathrm{A} / \mathrm{J}) \mathrm{F} 1(\mathrm{~B} 6 \mathrm{AF} 1)$ mice after immunization in Freund's complete or incomplete adjuvant. The histology of the lesion was reminiscent of the picture of human oöphoritis. ZP3-specific $\mathrm{T}$ cell responses and antibodies directed to $\mathrm{ZP} 3$ were detectable in these ZP3-immunized animals (273). In an adoptive transfer experiment to naive mice, ZP3-specific CD4 ${ }^{+} \mathrm{T}$ cells were sufficient for induction of the oöphoritis without observable antibody production to the ZP. The ZP3-specific $\mathrm{CD}^{+}{ }^{+} \mathrm{T}$ cells mainly produced IL-2, IFN- $\gamma$, and TNF, but not IL-4, indicating that the disease-specific T cells belonged to the TH1 subset of $\mathrm{CD}^{+}{ }^{+} \mathrm{T}$ cells.

Subsequently, Lou and Tung (275) very elegantly showed that a transfer of $\mathrm{T}$ cells that were directed to the small $\mathrm{T}$ cell epitope of ZP3 (15-amino acid peptide) alone differed from the adoptive transfer of $\mathrm{T}$ cells to whole ZP3. The former transfer could already result in a full-blown autoimmune oöphoritis, and, apart from a $\mathrm{T}$ cell response to the selfpeptide and histomorphologically confirmed oöphoritis, serum antibodies to native ZP3 and preferential binding of the antibody to the ZP in vivo were found. Crucial in the experiments was the presence of the ovaries during the antigenspecific $\mathrm{CD}^{+}{ }^{+} \mathrm{T}$ cell transfer. The phenomenon shows that $\mathrm{B}$ cells autoreactive to ovarian antigens can be generated after a $\mathrm{T}$ cell transfer, and that these cells can be activated by ZP3-specific $\mathrm{CD}^{+} \mathrm{T}$ cells to produce antibodies that are directed to and bind ZP3 in vivo. It is thought that the ovarian antigen required for antibody production in this model is provided by the normal ovaries, since the ZP antigens may be generated through a process of follicular atresia (epitope spreading).

Another mechanism by which the ZP autoantibodies can be induced is by idiotype mimicry of autoantigens in the absence of the antigen itself. Tung and colleagues (276) also investigated whether a nonovarian peptide could be recognized by ZP3-specific T cells. The author detected, by searching the protein sequence library, nonovarian peptides sharing sufficient residues with ZP3. Interestingly, the $\delta$-chain of the murine acetylcholine receptor and the ZP3 peptide had certain homology. The ZP3 peptide derivate and the $\delta$-chain of the acetylcholine receptor both elicited severe oöphoritis and also stimulated the ZP3-specific T cell clone to proliferate. Through the mechanism of $\mathrm{T}$ cell peptide mimicry, using a $\delta$-chain of the murine acetylcholine receptor, autoimmune oöphoritis could be elicited by clonal activation of ZP3-specific pathogenic T cells. Hence, T cell epitope mimicry as autoimmune disease mechanism was detected in the murine model, and this mimicry may explain the clinical association between POF and myasthenia gravis. Unfortunately, however, in the human there does not exist a homology between ZP3 and the acetylcholine receptor (277). Still, it remains remarkable that there is a marked coincidence between POF and myasthenia gravis (Table 5). The fact that in human oöphoritis a clear perineural infiltration of the ovarian hilus nerves is seen might also suggest a shared pathogenic mechanism between ovarian and neuronal diseases.

\section{Neonatal thymectomy models}

Neonatal thymectomy in BALB/c mice (and also some other strains, see below) at day 3 after birth results in oöphoritis, among other organ-specific autoimmune manifestations such as thyroiditis, gastritis, and parotitis (278-280). The inflammations are characterized by the presence of T cell infiltrates in the affected organs and the development of organ-specific antibodies in the serum. There is a strict temporal relationship between the development of the autoimmune syndrome and the day of thymectomy, which has to occur between the second and the fifth day after birth (280, 281). An explanation for the phenomenon has been proposed and is based on the premise that self-reactive $\mathrm{CD}^{+} \mathrm{T}$ cells are generated in the thymus throughout life and exported to the periphery. In euthymic animals, autoimmune disease is not observed because these autoreactive $\mathrm{CD}^{+} \mathrm{T}$ cells are controlled by $\mathrm{CD}^{+} \mathrm{T}$ cells with regulatory or suppressor activity. These cells are also generated in the thymus, but only after the first week of life. Hence thymectomy at day 3 , restricting the $\mathrm{T}$ cell repertoire to only effector autoimmune $\mathrm{CD}^{+}{ }^{+} \mathrm{T}$ cells, explains the spontaneously occurring autoimmune diseases, because the balance between self-reactive $\mathrm{T}$ cells and regulatory $\mathrm{T}$ cells tips over to the former.

That animal oöphoritis is directly due to autoimmune $\mathrm{T}$ cells is shown by transfer experiments of $\mathrm{CD}^{+} \mathrm{T}$ cells of thymectomized donors to young recipients, which causes an oöphoritis in these recipients $(282,283)$. This transfer of oöphoritis could be prevented by infusion of $\mathrm{CD}^{+} \mathrm{CD}^{+} \mathrm{T}$ cells from normal adult mice in an early stage after the transfer of the $\mathrm{CD}^{+}$cells of the thymectomized donors.

The histopathological events of the oöphoritis in the thymectomized mice occur in an orderly manner. Initially the oöphoritis is evident as a patchy or diffuse infiltration of lymphocytes; later, developing follicles are clearly affected and monocytes, macrophages, neutrophils, and plasma cells are found between and within ovarian follicles. The onset of puberty markedly potentiates the oöphoritis, indicating that probably a change in antigen profile due to the gonadotropin stimulation is important. The oöphoritis is most severe between 4-14 weeks after thymectomy. This is accompanied by loss of ova and collapse of ovarian follicles. Autoantibodies are detected in the circulation by week 4 , with a peak between weeks 7-9. Autoantibodies are directed toward oocytes, ZP, and in lower titers also to steroid-producing cells such as the granulosa cells, the theca cells, and the luteal cells. The inflammation subsides after 14 weeks, and the ovary becomes atrophic (278-280). IgG-producing plasma cells are found, but not frequently. The overall picture of the oöphoritis is one of a cell-mediated autoimmune reaction.

With regard to the genetics of this ovarian autoimmunity model, certain strains of mice are susceptible, such as the $\mathrm{BALB} / \mathrm{c}$ and $\mathrm{A} / \mathrm{J}$ mice, whereas other strains $(\mathrm{C} 57 \mathrm{bl} / 6 \mathrm{~J}$, DBA/2 mice) are resistant. Since susceptability and resistance are not associated with the MHC haplotype $(\mathrm{H} 2)$ of the mice, these molecules are apparently of minor importance. Using the susceptible and resistant mice strains and backcrosses of these strains in combination with a microsatellite approach, a locus has been found on chromosome 16, controlling the abrogation of the tolerance due to neonatal 
thymectomy day 3 (284). This so-called Aod1 locus was associated with the presence of oöphoritis in the mice. Interestingly, the markers on chromosome 16 failed to exhibit a significant linkage to the concomitant ovarian atrophy in this mouse oöphoritis model. Rather, this atrophy exhibited an association with markers on mouse chromosome 3 (284).

With regard to another experimental mouse model of gonadal autoimmunity, viz the male counterpart of allergic oöphoritis, experimental allergic orchitis, studies have shown a similar complexity of gene involvement and the recognition of various susceptibility and resistance loci (the Orch genes) (285). In this model the H2 locus is of importance as a susceptibility locus, and the so-called Orch 1 gene has been mapped to the Hsp 70.3/G7 interval within the H-2S/ $\mathrm{H}-2 \mathrm{D}$ region. Genes controlling resistance have also been identified: Orch 3 maps centrally on chromosome 11, while Orch 4 maps on chromosome 1. Orch 5, also on chromosome 1 , is probably a gene governing the extent of the inflammatory lesions seen in susceptable mice. Most significant is the linkage of Orch 3 to Idd-4 and Orch 5 to Idd-5, two susceptibility genes that play a role in IDDM of the NOD mouse model (see above and Table 2).

The histological and serological manifestations of the murine autoimmune oöphoritis are comparable to the histological and serological picture of human autoimmune oöphoritis in association with Addison's disease. It is remarkable, however, that the adrenal glands are unaffected in the neonatally thymectomized mice, even in the presence of antibodies to steroid-producing cells. However, modifications of the model, viz immunomodulation using Cyclosporin A after birth, does affect the adrenals (261).

As the inflammation of the ovaries subsides, serum antioocyte and anti-zona antibodies also decrease to sometimes undetectable levels at day 150-360, when oocytes have completely disappeared from the atrophic ovary (278-280). Therefore, the absence of serum autoantibodies does not exclude an autoimmune etiology of the ovarian disease. This finding may be of relevance in patients with adrenalitis and/or amenorrhea; detection of St-C-Abs may not always be expected unless they are looked for in an early stage of the disease.

\section{Transfer of normal $T$ cells to athymic (nu/nu) mice}

Yet another mechanism for the induction of an autoimmune oöphoritis is the transfer of $\mathrm{T}$ cells to athymic nude mice.

The nude mouse model is characterized by a deficient $\mathrm{T}$ cell function because the most important function of the thymus, education of $\mathrm{T}$ cells to properly recognize self and nonself, cannot take place. When CD4+CD8-thymocytes from normal neonatal or adult BALB/c mice are transferred to athymic mice, approximately $50-75 \%$ of the recipients develop an autoimmune oöphoritis and/or gastritis (264). Neonatal $\mathrm{CD}^{+}{ }^{+}$splenocytes are also able to transfer the autoimmune diseases, whereas T cells from adult spleen do not (286). However, a fraction of adult spleen $\mathrm{CD}^{+}$with a low expression of $\mathrm{CD}^{+}$can induce oöphoritis in athymic recipients. The disease-generating $\mathrm{CD}^{+} \mathrm{T}$ cells are of the Th1 type. Regulatory $\mathrm{T}$ cells that down-regulate self-reactive $\mathrm{T}$ cells in this animal model are also present, as studied by the combined infusion of neonatal spleen cells that enhance autoimmune oöphoritis and adult spleen cells that inhibit this process (264). The exact nature of these regulatory cells in this animal model is not yet elucidated; however, it is hypothesized that these belong to the Th2 subset of the CD4 ${ }^{+}$T cells.

The ovarian histopathology of day 3 thymectomized animals and nude mice that develop an oöphoritis after an adoptive transfer experiment are indistinguishable; hence it might be a good model for POF in the presence of adrenal autoimmunity/Addison's disease.

In the human situation, experiments of nature show us that athymic girls show evidence of dysgenetic, atrophic ovaries, devoid of follicles (287). Whether this is the ultimate consequence of an autoimmune process that began very early on remains hypothetical.

\section{E. Conclusions}

The murine animal oöphoritis models of neonatal thymectomy or $\mathrm{T}$ cell transfer in the nude animal clearly show that pathogenic self-reactive $\mathrm{T}$ cells exist in the normal neonatal and adult repertoire of at least the mouse, and that these autoreactive effector $\mathrm{T}$ cells are controlled by regulatory $\mathrm{T}$ cells also existing in the normal adult repertoire. There evidently exists a genetically controlled balance between these two T cell populations that ensures tolerance to ovarian and other self-antigens. When the balance tips over in favor of effector T cell activity, autoimmune oöphoritis develops (often in association with thyroiditis and other endocrine autoimmune disorders). This type of murine autoimmune oöphoritis is histologically and serologically similar to the human autoimmune oöphoritis occurring in association with adrenal autoimmunity and Addison's disease ( $\sim 2-10 \%$ of POF cases). The autoantibodies and the histology of this type of POF shows that steroid-producing cells are one of the main targets of the autoimmune response, and autoantigens of these steroid-producing cells are gradually identified (important enzymes in steroid synthesis). When all the data are considered together, POF in association with adrenal autoimmunity and/or Addison's disease and positive for St-CAbs can now with certainty be considered as an endocrine autoimmune disease.

The animal models of immunization with crude and purified $\mathrm{ZP}$ antigens demonstrate that autoimmune ovarian failure can also be reached via other histological pictures and mechanisms. First, there is the follicular infiltration by various immune cells in the ZP3-peptide immunization model, similar to the thymectomy model and the $\mathrm{T}$ cell transfer model in athymic nude mice. This picture is again reminiscent of the autoimmune oöphoritis seen in POF patients with St-C-Abs and associated with Addison's disease. The infiltration ultimately leads to follicular depletion and fibrosis. Second, there is the simple depletion of follicles after immunization with crude ZP antigens in the absence of a clear lymphocytic infiltration, but with the production of antibodies. This model might be most relevant for POF cases without adrenal involvement and with fibrotic ovaries. Also in the human, ZP autoantibodies have been detected and there is some, though weak, evidence that such POF cases belong to 
the group of autoimmune diseases (associations with other autoimmune diseases, abnormal numbers and functions of peripheral lymphocytes and monocytes; see earlier discussions in this review). However, further experiments are required to establish or refute such a view.

\section{Summary}

Premature ovarian failure (POF) is defined as a syndrome characterized by menopause before the age of $40 \mathrm{yr}$. The patients suffer from anovulation and hypoestrogenism. Approximately $1 \%$ of women will experience menopause before the age of $40 \mathrm{yr}$. POF is a heterogeneous disorder with a multicausal pathogenesis involving chromosomal, genetic, enzymatic, infectious, and iatrogenic causes. There remains, however, a group of POF patients without a known etiology, the so-called "idiopathic" form. An autoimmune etiology is hypothesized for the POF cases with a concomitant Addison's disease and/or oöphoritis.

It is concluded in this review that POF in association with adrenal autoimmunity and/or Addison's disease (2-10\% of the idiopathic POF patients) is indeed an autoimmune disease. The following evidence warrants this view: 1) The presence of autoantibodies to steroid-producing cells in these patients; 2) The characterization of shared autoantigens between adrenal and ovarian steroid-producing cells; 3) The histological picture of the ovaries of such cases (lymphoplasmacellular infiltrate around steroid-producing cells); 4) The existence of various autoimmune animal models for this syndrome, which underlines the autoimmune nature of the disease.

There is some circumstantial evidence for an autoimmune pathogenesis in idiopathic POF patients in the absence of adrenal autoimmunity or Addison's disease. Arguments in support of this are: 1) The presence of cellular immune abnormalities in this POF patient group reminiscent of endocrine autoimmune diseases such as IDDM, Graves' disease, and Addison's disease; 2) The more than normal association with IDDM and myasthenia gravis. Data on the presence of various ovarian autoantibodies and anti-receptor antibodies in these patients are, however, inconclusive and need further evaluation.

A strong argument against an autoimmune pathogenesis of POF in these patients is the nearly absent histological confirmation (the presence of an oöphoritis) in these cases $(<3 \%)$. However, in animal models using ZP immunization, similar follicular depletion and fibrosis (as in the POF women) can be detected.

Accepting the concept that POF is a heterogenous disorder in which some of the idiopathic forms are based on an abnormal self-recognition by the immune system will lead to new approaches in the treatment of infertility of these patients. There are already a few reports on a successful ovulation-inducing treatment of selected POF patients (those with other autoimmune phenomena) with immunomodulating therapies, such as high dosages of corticosteroids (288-292).

\section{Acknowledgments}

The assistance of Martha Canning in correcting the English language of the manuscript is acknowledged with thanks, as is the secretarial assistance of Petra Assems.

\section{References}

1. de Moraes-Ruehsen M, Jones GS 1967 Premature ovarian failure. Fertil Steril 18:440-461

2. Singh RP, Carr DH 1966 The anatomy and histology of XO human embryos and fetuses. Anat Rec 155:369-383

3. Villanueva AL, Rebar RW 1983 Triple-X syndrome and premature ovarian failure. Obstet Gynecol 62[Suppl 3]:70s-73s

4. Fitch N, de Saint Victor J, Richer CL, Pinsky L, Sitahal S 1982 Premature menopause due to a small deletion in the long arm of the $\times$ chromosome: a report of three cases and a review. Am J Obstet Gynecol 142:968-972

5. Krauss CM, Turksoy RN, Atkins L, McLaughin C, Brown L, Page DC 1987 Familial premature ovarian failure due to an interstitial deletion of the long arm of the $\times$ chromosome. $N$ Engl J Med 317:125-131

6. Trunca C, Therman E, Rosenwaks Z 1984 The phenotypic effect of small, distal Xq deletions. Hum Genet 68:87-89

7. Fitzgerald PH, Donald RA, McCormick P 1984 Reduced fertility in women with chromosome abnormalities. Clin Genet 25:301-309

8. Hens L, Devroey $P$, van Waesberghe L, Bonduelle $M$, van Steirteghem AC, Liebaers I 1989 Chromosome studies and fertility treatment in women with ovarian failure. Clin Genet 36:81-91

9. Plunkett ER, Garner PR 1972 Ovarian failure: possible etiological mechanisms. In: Velardo JT, Kasprow BA (eds) Biology of Reproduction: Basic and Clinical studies. Presented at the Pan American Congress of Anatomy, New Orleans, pp 235-239

10. Smith A, Fraser IS, Noel M 1979 Three siblings with premature gonadal failure. Fertil Steril 32:528-530

11. Coulam CB, Stringfellow S, Hoefnagel D 1983 Evidence for a genetic factor in the etiology of premature ovarian failure. Fertil Steril 40:693-695

12. Mattison DR, Evans MI, Schwimmer WB, White BJ, Jensen B, Schulman JD 1984 Familial premature ovarian failure. Am J Hum Genet 36:1341-1348

13. Chen YT, Mattison DR, Feigenbaum L, Fukui H, Schulman JD 1981 Reduction in oocyte number following prenatal exposure to a diet high in galactose. Science 214:1145-1147

14. Kaufman F, Kogut MD, Donnell GN, Koch R, Goebelsmann U 1979 Ovarian failure in galactosemia. Lancet 2:737-738

15. Waxman J 1983 Chemotherapy and the adult gonad: a review. J R Soc Med 76:144-148

16. Warne G1 Fairley KF, Hobbs JB, Martin FIR 1973 Cyclophosphamide-induced ovarian failure. N Engl J Med 289:1159-1162

17. Whitehead E, Shalet SM, Blackledge G, Todd I, Crowther D, Bearwell CG 1983 The effect of combination chemotherapy on ovarian function in women treated for Hodgkin's disease. Cancer 52:988-993

18. Le Floch O, Donaldson SS, Kaplan HS 1976 Pregnancy following oophoropexy and total nodal irradiation in women with Hodgkin's disease. Cancer 38:2263-2268

19. Byrne J, Fears TR, Gail MH, Pee D, Connelly RR, Austin DF, Holmes GF, Holmes FF, Latourette HB, Meigs JW, Strong LC, Myers MH, Mulvihill JJ 1992 Early menopause in long-term survivors of cancer during adolescence. Am J Obstet Gynecol 166: $788-793$

20. Horning SJ, Hoppe RT, Kaplan HS, Rosenberg SA 1981 Female reproductive potential after treatment for Hodgkin's disease. N Engl J Med 304:1377-1382

21. Morrison JC, Givens JR, Wiser WL, Fish SA 1975 Mumps oöphoritis: a cause of premature menopause. Fertil Steril 26:655-659

22. Prinz W, Taubert HD 1969 Mumps in pubescent females and its effect on later reproductive function. Gynaecologia 167:23-27

23. Coulam CB 1982 Premature gonadal failure. Fertil Steril 38:645-655

24. Jaszmann L, van Lith ND, Zaat JCA 1969 The age at menopause in the Netherlands: the statistical analysis of a survey. Int J Fertil 14:106-117 
25. Krailo MD, Pike MC 1983 Estimation of the distribution of age at natural menopause from prevalence data. Am J Epidemiol 117: 356-361

26. Walsh RJ 1978 The age of menopause of Australian women. Med J Aust 2:181-182

27. Baker TG 1973 A quantatitive and cytological study of germ cells in human ovaries. Proc R Soc Lond [Biol] 158:417-433

28. Block E 1952 Quantitative morphological investigations of the follicular system in women. Variations at different ages. Acta Anat (Basel) 14:108-123

29. Costoff A, Mahesh VB 1975 Primordial follicles with normal oocytes in the ovaries of postmenopausal women. J Am Geriatr Soc 23:193-196

30. Cameron IT, O'Shea FC, Rolland JM, Hughes EG, de Kretser DM, Healy DL 1988 Occult ovarian failure: a syndrome of infertility, regular menses, and elevated follicle-stimulating hormone concentrations. J Clin Endocrinol Metab 67:1190-1194

31. Heller CG, Heller EJ 1939 Gonadotropic hormone: assays of normal cycling, menopausal, castrated and estrin treated females. J Clin Invest 18:171-178

32. Atria A 1950 La menopausia precoz y su tratamiento hormonal. Rev Med Chile 78:373-377

33. Starup J, Sele V 1973 Premature ovarian failure. Acta Obstet Gynecol Scand 52:259-268

34. Alper MM, Garner PR 1985 Premature ovarian failure: its relationship to autoimmune disease. Obstet Gynecol 66:27-30

35. Philip J, Sele V, Trolle D 1966 Secondary hypergonadotrophic amenorrhea. Acta Obstet Gynecol Scand 45:142-147

36. Sele V, Starup J 1971 Premature ovarian failure. Acta Obstet Gynecol Scand 50:24

37. Zarate A, Karchmer S, Gomez E, Castelazo-Ayala L 1970 Premature menopause. A clinical, histologic, and cytogenetic study. Am J Obstet Gynecol 106:110-114

38. Emperaire JC, Audebert A, Greenblatt RB 1970 Premature ovarian failure. Report of seven cases. Am J Obstet Gynecol 108:445-449

39. Starup J, Sele V, Henriksen B 1971 Amenorrhoea associated with increased production of gonadotrophins and morphologically normal ovarian follicular apparatus. Acta Endocrinol (Copenh) 66: 248-256

40. Yen SS, Tsai CC, Vandenberg G, Rebar R 1972 Gonadotropin dynamics in patients with gonadal dysgenesis: a model for the study of gonadotropin regulation. J Clin Endocrinol Metab 35:897904

41. Rebar RW, Erickson GF, Yen SS 1982 Idiopathic premature ovarian failure: clinical and endocrine characteristics. Fertil Steril 37: 35-41

42. Alper MM, Jolly EE, Garner PR 1986 Pregnancies after premature ovarian failure. Obstet Gynecol 67[Suppl 3]:59s-62s

43. Schreiber JR, Davajan V, Kletsky OA 1978 A case of intermittent ovarian failure. Am J Obstet Gynecol 132:698-699

44. Alper MM, Garner PR, Seibel MM 1986 Premature ovarian failure: current concepts. J Reprod Med 31:699-708

45. Wright CS, Jacobs HS 1979 Spontaneous pregnancy in a patient with hypergonadotropic ovarian failure. Br J Obstet Gynecol 86: 389-392

46. Jeppsson S, Ljungberg O, Rannevik G 1980 Hypergonadotropic hypogonadism with preserved fertility: a new syndrome? Acta Endocrinol (Copenh) 95:388-392

47. Nelson LM, Anasti JN, Kimzey LM, Defensor RA, Lipetz KJ, White BJ, Shawker TH, Merino MJ 1994 Development of luteinized graafian follicles in patients with karyotypically normal spontaneous premature ovarian failure. J Clin Endocrinol Metab 79: $1470-1475$

48. Coulam CB, Adamson SC, Annegers JF 1986 Incidence of premature ovarian failure. Obstet Gynecol 67:604-606

49. Kinch RAH, Plunkett ER, Smout MS, Carr DH 1965 Primary ovarian failure: a clinicopathological and cytogenetic study. Am J Obstet Gynecol 91:630-641

50. Jones GS, de Moraes-Ruehsen M 1969 A new syndrome of amenorrhea in association with hypergonadotropism and apparently normal ovarian follicular apparatus. Am J Obstet Gynecol 104:597600

51. Fraser IS, Shearman RP, Smith A, Russell P 1988 An association among blepharophimosis, resistant ovary syndrome, and true premature menopause. Fertil Steril 50:747-751

52. Panidis D, Rousso D, Vavilis D, Skiadopoulos S, Kalogeropoulos A 1994 Case report. Familial blepharophimosis with ovarian dysfunction. Hum Reprod 9:2034-2037

53. Fraser IS, Russell P, Greco S, Robertson DM 1986 Resistant ovary syndrome and premature ovarian failure in young women with galactosaemia. Clin Reprod Fertil 4:133-138

54. Townsend A, Bodmer H 1989 Antigen recognition by class I restricted T lymphocytes. Annu Rev Immunol 7:601-624

55. Hill JA, Welch WR, Faris HMP, Anderson DJ 1990 Induction of class II major histocompatibility complex antigen expression in human granulosa cells by interferon gamma: a potential mechanism contributing to autoimmune ovarian failure. Am J Obstet Gynecol 162:534-540

56. Freudenthal PS, Steinman RM 1990 The distinct surface of human blood dendritic cells, as observed after an improved isolation method. Proc Natl Acad Sci 87:7698-7702

57. Weetman AP 1991 Immunogenetics and autoimmunity. In: Weetman AP (ed) Autoimmune Endocrine Disease. Cambridge Reviews in Clinical Immunology. Cambridge University Press, pp 39-65

58. Strominger JL 1987 Structure class I and class II HLA antigens. Br Med Bull 43:81-93

59. Pure E, Inaba K, Crowley MT, Tardelli L, Witmer-Pack MD, Ruberti G, Fathman G, Steinman RM 1990 Antigen processing by epidermal Langerhans cells correlates with level of biosynthesis of major histocompatibility complex class II molecules and expression of invariant chain. J Exp Med 172:1459-1469

60. Neefjes JJ, Ploegh HL 1992 Intracellular transport of MHC class II molecules. Immunol Today 13:179-184

61. Harding CV 1993 Cellular and molecular aspects of antigen processing and the function of class II molecules. Am J Respir Cell Mol Biol 8:461-467

62. Rock KL, Rothstein L, Gamble S, Fleischacker C 1993 Characterization of antigen-presenting cells that present exogenous antigens in association with class I MHC molecules. J Immunol 150:438-446

63. Rudensky AYu Preston-Hulburt P, Hong SC, Barlow A, Janeway Jr CA 1991 Sequence analysis of peptide bound to MHC class II molecules. Nature 353:622-627

64. Monaco JJ, McDevitt HO 1984 H-2 linked low-molecular weight polypeptide antigens assemble into an unusual macromolecular complex. Nature 309:797-799

65. Falk K, Rotzschke O, Stevanovic S, Jung G, Rammensee HG 1991 Allele-specific motifs revealed by sequencing of self peptides eluted from MHC molecules. Nature 351:290-296

66. Teh HS, Kisielow P, Scott B, Kishi H, Vematsu Y, Bluthmann H, von Boehmer H 1988 Thymic major histocompatibility complex antigens and the alpha-beta T cell receptor determine the CD4/CD8 phenotype of T cells. Nature 335:229-233

67. Germain RN 1994 MHC dependent antigen processing and peptide presentation: providing ligands for T lymphocyte activation. Cell 76:287-299

68. Jin Y, Shih WK, Berkower I 1988 Human T cell response to the surface antigen of hepatitis B virus (HBsAg). Endosomal and nonendosomal processing pathways are accessible to both endogenous and exogenous antigen. J Exp Med 168:293-306

69. Austyn JM, Smith KG, Morris PJ 1987 T cell activation by anti-CD3 antibodies: function of $F_{c}$ receptors on $B$ cell blasts, but not resting B cells, and CD18 on the responding T cells. Eur J Immunol 17: 1329-1335

70. Bohmig GA, Kovarik J, Holter W, Pohanka E, Zlabinger GJ 1994 Specific downregulation of proliferative $T$ cell alloresponsiveness by interference with CD2/LFA-3 and LFA-1/ICAM-1 in vitro. J Immunol 152:3720-3728

71. Teunissen MB, Rongen HA, Bos JD 1994 Function of adhesion molecules lymphocyte function-associated antigen-3 and intercellular adhesion molecule- 1 on human epidermal Langerhans cells in antigen-specific T cell activation. I Immunol 152:3400-3409

72. Mueller DL, Jenkins MK, Schwartz RH 1989 Clonal expansion vs. functional clonal inactivation: a co-stimulatory signalling pathway determines the outcome of T-cell antigen receptor occupancy. Annu Rev Immunol 7:445-480 
73. Allison JP 1994 CD28-B7 interactions in T cell activation. Curr Opin Immunol 6:414-419

74. Norton SD, Zuckerman L, Urdahl KB, Shefner R, Miller J, Jenkins MK 1992 The CD28 ligand, B7, enhances Il-2 production by providing a co-stimulatory signal to T-cells. J Immunol 149:1556-1561

75. June CH, Bluestone JA, Nadler LM, Thompson CB 1994 The B7 and CD28 receptor families. Immunol Today 15:321-331

76. Austyn JM 1987 Lymphoid dendritic cells. Immunology 62:161170

77. Steinman RM 1991 The dendritic cell system and its role in immunogenicity. Annu Rev Immunol 9:271-296

78. van Voorhis WC, Valinsky J, Hoffman E, Luban J, Hair LS, Steinman RM 1983 Relative efficacy of human monocytes and dendritic cells as accessory cells for T cell replication. J Exp Med 158:174-191

79. Caux C, Liu YS, Banchereau J 1995 Recent advances in the study of dendritic cells and follicular dendritic cells. Immunol Today 16:2-4

80. Prickett TCR, McKenzie JL, Hart DNJ 1992 Adhesion molecules of human tonsil dendritic cells. Transplantation 53:483-490

81. Hart DNJ, Prickett TCR 1993 Intercellular adhesion molecule-2 (ICAM-2) expression on human dendritic cells. Cell Immunol 148: 447-454

82. Inaba K, Steinman RM 1987 Monoclonal antibodies to LFA-1 and to CD4 inhibit the mixed leucocyte reaction after the antigen dependent clustering of dendritic cells and T lymphocytes. J Exp Med 165:1403-1417

83. Hart DN, Starling GC, Calder VL, Fernando NS 1993 B7/BB1 is a leucocyte differentiation antigen on human dendritic cells induced by activation. Immunology 79:616-620

84. Kamperdijk EWA, van Vught E, Richters CD Beelen RHJ 1994 Morphology of dendritic cells. In: Bruijnzeel-Koomen CAFM, Hoefsmit ECM (eds) Immunopharmacology of Macrophages and Other Antigen-Presenting Cells. Academic Press Harcourt Brace and Company, New York, pp 45-61

85. Witmer MD, Steinman RM 1984 The anatomy of peripheral lymphoid organs with emphasis on accessory cells: light microscopic immunocytochemical studies of mouse spleen, lymh node, and Peyer's patch. Am J Anat 170:465-481

86. Vakkila J, Sihvola M, Hurme M 1990 Human peripheral bloodderived dendritic cells do not produce interleukin 1-alpha, interleukin 1-beta or interleukin 6. Scand J Immunol 31:345-352

87. Hart DNJ, Calder VL 1993 Human dendritic cells: function and Cytokine production. In: Bruijnzeel-Koomen CAFM, Hoefsmit ECM (eds) Immunopharmacology of Macrophages and Other Antigen-Presenting Cells . Academic press Harcourt Brace and Company, New York, pp 63-91

88. Flechner ER, Freudenthal PS, Kaplan G, Steinman RM 1988 Antigen specific $\mathrm{T}$ lymphocytes efficiently cluster with dendritic cells in human primary mixed leucocyte reaction. Cell Immunol 111: 183-195

89. Austyn JM, Weinstein DE, Steinman RM 1988 Clustering with dendritic cells precedes and is essential for T-cell proliferation in a mitogenesis model. Immunology 63:691-696

90. Linsley PS, Clark EA, Ledbetter JA 1990 T-cell antigen CD28 mediates adhesion with B-cells by interacting with activation antigen B7/BB1. Proc Natl Acad Sci USA 87:5031-5035

91. Scott P 1993 Il-12: initiation cytokine for cell-mediated immunity. Science 260:496-497

92. Moore KV, O'Garra A, de Waal Malefyt R, Vieira P, Mosmann TR 1993 Interleukin 10. Annu Rev Immunol 11:165-190

93. d'Andrea A, Aste-Amezaga M, Valiante NM, Ma X, Kubin M, Trinchieri G 1993 Interleukin 10 (IL-10) inhibits human lymphocyte interferon gamma-production by suppressing natural killer cell stimulatory factor/Il-12 synthesis in accessory cells. J Exp Med 178:1041-1048

94. Nossal GJV 1987 Current concepts: immunology. The basic components of the immune system. N Engl J Med 316:1320-1325

95. Cooper MD 1987 Current concepts. B lymphocytes: normal development and function. N Engl J Med 317:1452-1456

96. Marrack P, Kappler J 1987 The T cell receptor. Science 238: 1073-1079
97. Royer HD, Reinherz EL 1987 T lymphocytes: ontogeny, function, and relevance to clinical disorders. N Engl J Med 317:1136-1142

98. Meuer SC, Acuto O, Hercend T, Schlossman SF, Reinherz EL 1984 The human T-cell receptor. Annu Rev Immunol 2:23-50

99. Moss PA, Rosenberg WM, Bell JI 1992 The human T cell receptor in health and disease. Annu Rev Immunol 10:71-96

100. Brenner MB, McLean J, Dialynas DP, Strominger JL, Smith JA, Owen FL, Seidman JG, Ip S, Rosen F, Krangel MS 1986 Identification of putative second T-cell receptor. Nature 322:145-149

101. Brenner MB, McLean J, Scheft H, Riberdy J, Ang SL Seidman JG, Devlin P, Krangel MS 1987 Two forms of the T-cell receptor gamma protein found on peripheral blood cytotoxic T lymphocytes. Nature 325:689-694

102. Allison JP, Lanier LL 1987 Structure, function, and serology of the T-cell antigen receptor complex. Annu Rev Immunol 5:503-540

103. Leder P 1982 The genetics of antibody diversity. Sci Am 246: $102-115$

104. Tonegawa S 1983 Somatic generation of antibody diversity. Nature 302:575-581

105. Oettgen HC, Kappler J, Tax WJ, Terhorst C 1984 Characterization of the two heavy chains of the T3 complex on the surface of human T lymphocytes. J Biol Chem 259:12039-12048

106. Borst J, Coligan JE, Oettgen H, Pessano S, Malin R, Terhorst C 1984 The delta and epsilon chains of the human T3/T-cell receptor complex are distinct polypeptides. Nature 312:455-458

107. Collins TL, Kassner PD, Bierer BE, Burakoff SJ 1994 Adhesion receptors in lymphocyte activation. Curr Opin Immunol 6:385-393

108. Bierer BE, Sleckman BP, Ratnofsky SE, Burakoff SJ 1989 The biologic roles of CD2, CD4, and CD8 in T-cell activation. Annu Rev Immunol 7:579-599

109. Mosmann TR, Coffman RL 1989 Th1 and Th2 cells: different patterns of lymphokine secretion lead to different functional properties. Annu Rev Immunol 7:145-173

110. Romagnani S 1989 Human Th1 and Th2 subsets: regulation of differentiation and role in protection and immunopathology. Int Arch Allergy Immunol 98:279-285

111. Powrie F, Menon S, Coffman RL 1993 Interleukin-4 and interleukin-10 synergize to inhibit cell-mediated immunity in vivo. Eur J Immunol 23:2223-2229. (published erratum appears in Eur J Immunol 1994 24:785)

112. Quill H, Gaur A, Phipps RP 1989 Prostaglandin E2-dependent induction of granulocyte-macrophage colony-stimulating factor secretion by cloned murine helper T cells. J Immunol 142:813-818

113. Betz M, Fox BS 1991 Prostaglandin E2 inhibits production of Th1 lymphokines but not of Th2 lymphokines. J Immunol 146:108-113

114. Munoz E, Zubiaga AM, Merrow M, Sauter NP, Huber BT 1990 Cholera toxin discriminates between $\mathrm{T}$ helper 1 and 2 cells in $\mathrm{T}$ receptor-mediated activation: role of $\mathrm{cAMP}$ in $\mathrm{T}$ cell proliferation. J Exp Med 172:95-103

115. Johnson HM, Torres BA 1984 Leukotrienes: positive signals for regulation of gamma-interferon production. J Immunol 132:413416

116. Myers CD 1991 Role of B cell antigen processing and presentation in the humoral immune response. FASEB J 5:2547-2553. (published erratum appears in FASEB J 1991 5:285)

117. Parker DC 1993 T cell-dependent B cell activation. Annu Rev Immunol 11:331-360

118. Burton DR 1987 Structure and function of antibodies. In: Calabi F, Neuberger MS (eds) Molecular Genetics of Immunoglobulin. Elsevier Science Publishers. Amsterdam, pp 1-50

119. Shimizu A, Honjo T 1984 Immunoglobulin class switching. Cell 36:801-803

120. Krawinkel U, Radbuch A 1987 Immunoglobulin heavy chain class switctching. In: Calabi F, Neuberger MS (eds) Molecular Genetics of Immunoglobulin. Elsevier Science Publishers, Amsterdam, pp 135-151

121. Griffin Jr FM, Griffin JA, Leider JE, Silverstein SC 1975 Studies on the mechanism of phagocytosis. I. Requirements for circumferential attachment of particle-bound ligands to specific receptors on the macrophage plasma membrane. J Exp Med 142:1263-1282

122. Campbell PA, Canono BP, Cook JL 1988 Mouse macrophages stimulated by recombinant gamma-interferon to kill tumor cells are 
not bactericidal for facultative intracellular bacterium Listeria monocytogenes. Infect Immun 56:1371-1375

123. Green JG, Turpin JA, Nacy CA 1995 Cytotoxic effector activities of macrophages. In: RR Rich, TA Fleischer, BD Schwartz, WT Shearer, W Strober (eds) Clinical Immunology, Principles and Practice. Mosby 1996, St. Louis, MO, vol 1:290-298

124. Leibovich SJ, Polverini PJ, Shepard HM, Wiseman DM, Shively V, Nuseir N 1987 Macrophage-induced angiogenesis is mediated by tumor necrosis factor-alpha. Nature 329:630-632

125. Pierce GF, Mustoe TA, Lingelbach J, Masakowski VR, Gramates P, Deuel TF 1989 Transforming growth factor beta reverses the glucocorticoid-induced wound-healing deficit in rats: possible regulation in macrophages by platelet-derived growth factor. Proc Natl Acad Sci USA 86:2229-2233

126. Greenberger JS 1991 The hematopoietic microenvironment. Crit Rev Oncol Hematol 11:65-84

127. van Ewijk W 1991 T-cell differentiation is influenced by thymic microenvironment. Annu Rev Immunol 9:591-615

128. Leenen PJM, Campbell PA 1993 Heterogeneity of mononuclear phagocytes. An interpretive review. In: Horton MA (ed) Blood Cell Biochemistry: Macrophages and Related cells. Plenum Press, New York, vol 5:29-85

129. van Furth R 1992 Development and distribution of mononuclear phagocytes. In: Gallin JI, Goldstein IM, Snijderman R (eds) Inflammation: Basic Principles and Clinical Correlates. Raven Press, New York

130. Trinchieri G 1989 Biology of natural killer cells. Adv Immunol 47:187-316

131. Lanier LL, Cwirla S, Federspiel N, Phillips J 1986 Human natural killer cells isolated from peripheral blood do not rearrange $\mathrm{T}$ cell antigen receptor beta chain genes. J Exp Med 163:209-214

132. Perussia B, London L, Trichieri G 1985 Phenotypic characteristics of human natural killer cells. Biomed Pharmacother 39:13-18

133. Lanier LL, Le AM, Civin CI, Loken MR, Phillips JH 1986 The relationship of CD16 (Le-11) and Leu-19 (NKH-1) antigen expression on human peripheral blood NK cells and cytotoxic T lymphocytes. J Immunol 136:4480-4486

134. Nagler A, Lanier LL, Phillips JH 1990 Constitutive expression of high affinity interleukin 2 receptors on human CD16-natural killer cells in vivo. J Exp Med 171:1527-1533

135. Herberman RB, Nunn ME, Holden HT, Lavrin DH 1975 Natural cytotoxic reactivity of mouse lymphoid cells against syngeneic and allogeneic tumors. II. Characterization of effector cells. Int J Cancer 16:230-239

136. Kiessling R, Klein E, Pross H, Wigzell H 1975 "Natural” killer cells in the mouse II. Cytotoxic cells with specificity for mouse Moloney leukemia cells. Characteristics of the killer cell. Eur J Immunol 5:117-121

137. Podack ER 1992 Perforin: structure, function, and regulation. Curr Top Microbiol Immunol 178:175-184

138. Seaman WE 1995 Natural killer cells. In: Rich RR, Fleischer TA, Schwartz BD, Shearer WT, Strober W (eds) Clinical Immunology, Principles and Practice. Mosby 1996, St. Louis, MO, vol 1:282-289

139. Yuan D, Koh CY, Wilder JA 1994 Interactions between B lymphocytes and NK cells. FASEB J 8:1012-1018

140. Suda T, Takahashi T, Golstein P, Nagata S 1993 Molecular cloning and expression of the Fas ligand, a novel member of the tumor necrosis factor family. Cell 75:1169-1178

141. Biddison WE 1995 Cytotoxic T cell function. In: Rich RR, Fleischer TA, Schwartz BD, Shearer WT, Strober W (eds) Clinical Immunology, Principles and Practice. Mosby 1996, St. Louis, MO, vol 1:276281

142. Kroemer G, Martinez C 1992 Mechanisms of self tolerance. Immunol Today 13:401-404

143. Kappler JW, Roehm N, Marrack P 1987 T cell tolerance by clonal elimination in the thymus. Cell 49:273-280

144. Murphy KM, Heimberger AB, Loh DY 1990 Induction of antigen of intrathymic apoptosis of CD4+CD8+TCR+ thymocytes in vivo. Science 250:1720-1723

145. Anonymous 1986 Autoimmunity: experimental and clinical aspects. Ann NY Acad Sci 475:1-427

146. Goodnow CC, Adelstein S, Basten A 1990 The need for central and peripheral tolerance in the B cell repertoire. Science 248:1373-1379
147. Kimura H, Davies TF 1991 Thyroid-specific T cells in the normal Wistar rat. II. T cell clones interact with cloned Wistar rat thyroid cells and provide direct evidence for autoantigen presentation by thyroid epithelial cells. Clin Immunol Immunopathol 58:195-206

148. Schwartz RH 1990 A culture model for T lymphocyte clonal anergy. Science 248:1349-1356

149. Morahan G, Allison J, Miller JF 1989 Tolerance of class I histocompatibility antigens expressed extrathymically. Nature 339:622624

150. Mohler KM, Streilein JW 1989 Differential expression of helper vs. effector activity in mice rendered neonatally tolerant of class II MHC antigens. Transplantation 47:633-640

151. Voorbij HA, Kabel PJ, de Haan M, Jeucken PH, van der Gaag RD, de Baets MH, Drexhage HA 1990 Dendritic cells and class II MHC expression on thyrocytes during autoimmune thyroid disease of the BB rat. Clin Immunol Immunopathol 55:9-22

152. Hanafusa T, Pujol-Borell R, Chiovato L, Doniach D, Russell RC, Doniach D, Bottazzo GF 1983 Aberrant expression of HLA-DR antigen on thyrocytes in Graves' disease: relevance for autoimmunity. Lancet 2:1111-1115

153. Iwatani Y, Amino N, Miyai K 1989 Peripheral self tolerance and autoimmunity: the protective role of expression of class II major histocompatibility antigens on non-lymphoid cells. Biomed Pharmacother 43:593-605

154. Miller A, Hafler DA, Weiner HL 1991 Tolerance and suppressor mechanisms in experimental autoimmune encephalomyelitis: implications for immunotherapy of human autoimmune diseases. FASEB J 5:2560-2566

155. Batchelor JR, Lombardi G, Lechler RI 1989 Speculations on the specificity of suppression. Immunol Today 10:37-40

156. Day MJ, Tse AG, Puklavec M, Simmonds SJ, Mason DW 1992 Targeting autoantigen to B cells prevents the induction of a cell mediated autoimmune disease in rats. J Exp Med 175:655-659

157. Milgrom F, Witebsky E 1962 Autoantibodies and autoimmune disease. JAMA 181:706-717

158. Bottazzo GF 1993 Banting Lecture. On the honey disease. A dialogue with socrates. Diabetes 42:778-800

159. Wick G, Brezinschek HP, Hala K, Dietrich H, Wolf H, Kroemer G 1989 The obese strain of chickens: an animal model with spontaneous autoimmune thyroiditis. Adv Immunol 47:433-500

160. Voorbij HA, van der Gaag RD, Jeucken PH, Bloot AM, Drexhage HA 1989 The goitre of the BB/O rat: an animal model for studying the role of immunoglobulins stimulating growth of thyroid cells. Clin Exp Immunol 76:290-295

161. Sakaguchi S, Sakaguchi N 1989 Organ-specific autoimmune disease induced in mice by elimination of T cell subsets. V. Neonatal administration of cyclosporin A causes autoimmune disease. J Immunol 142:471-480

162. Kabel PJ, Voorbij HA, de Haan M, van der Gaag RD, Drexhage HA 1988 Intrathyroidal dendritic cells. J Clin Endocrinol Metab 65:199-207

163. Many MC, Maniratunga S, Varis I, Dardenne M, Drexhage HA, Denef JF 1995 Two-step development of Hashimoto-like thyroiditis in genetically autoimmune prone non-obese diabetic mice: effects of iodine-induced cell necrosis. J Endocrinol 147:311-320

164. Yoon JW 1990 The role of viruses and environmental factors in the induction of diabetes. Curr Top Microbiol Immunol 164:95-123

165. Charlton B, Bacelj A, Slattery RM, Mandel TE 1989 Cyclophosphamide-induced diabetes in NOD/WEHI mice. Evidence for suppression in spontaneous autoimmune diabetes mellitus. Diabetes 38:441-447

166. Mooy P 1993 The Thyroid, Iodine and Autoimmunity. Thesis, University of Rotterdam, Rotterdam, The Netherlands

167. Colle E, Guttmann RD, Seemayer T 1981 Spontaneous diabetes mellitus syndrome in the rat. I. Association with major histocompatibility complex. J Exp Med 154:1237-1242

168. Todd JA, Aitman TJ, Cornall RJ, Ghosh S, Hall JR, Hearne CM, Knight AM, Love JM, McAleer MA, Prins JB, Rodrigues N, Lathrop M, Pressey A, DeLarato NH, Peterson LB, Wicker LS 1991 Genetic analysis of autoimmune type I diabetes mellitus in mice. Nature 351:542-547

169. Serreze DV, Gaedeke JW, Leiter EH 1993 Hematopoietic stem-cell defects underlying abnormal macrophage development and mat- 
uration in NOD/It mice: defective regulation of cytokine receptors and protein kinase C. Proc Natl Acad Sci USA 90:9625-9629

170. Greiner DL, Handler ES, Nakono K, Mordes JP, Rossini AA 1986 Absence of the RT-6 T cell subset in diabetes-prone BB/W rats. J Immunol 136:148-151

171. Volpe R 1988 The immunoregulatory disturbances in autoimmune thyroid disease. Autoimmunity 2:55-72

172. Wick G, Hu Y, Schwarz S, Kroemer G 1993 Immunoendocrine communication via the hypothalamo-pituitary-adrenal axis in autoimmune diseases. Endocr Rev 14:539-563

173. Wick G, Trieb K, Aguzzi A, Recheis H, Anderl H, GrubeckLoebenstein B 1993 Possible role of human foamy virus in Graves' disease. Intervirology 35:101-107

174. Theofilopoulos AN 1995 The basis of autoimmunity. II. Genetic predisposition. Immunol Today 16:150-159

175. Epplen JT, Buitkamp J, Bocker T, Epplen C 1995 Indirect gene diagnoses for complex (multifactorial) diseases. a review. Gene 159:49-55

176. van Dongen JJM, Groeneveld K, Adriaansen HJ, Hooijkaas H 1994 Immunofenotypering in de diagnostiek: indicatiestellingen, uitvoering en interpretatie. Afd. Immunologie, Erasmus Universiteit, Rotterdam, pp 27-40

177. Turkington RW, Lebovitz HE 1967 Extra-adrenal endocrine deficiencies in Addison's disease. Am J Med 43:499-507

178. Wulffraat NM, Drexhage HA, Bottazzo GF 1992 Autoimmune aspects of Addison's disease. In: James VHT (ed) The Adrenal Gland, ed 2. Raven Press, New York, pp 263-288

179. Munro Neville A, O'Hara MJ 1982 The Human Adrenal Cortex. Springer-Verlag, Berlin

180. Muir A, Schatz DA, MacLaren NK 1995 Autoimmune polyglandular syndrome. In: de Groot LS (ed) Endocrinology, ed. 3. WB Saunders, Philadelphia, pp 3013-3024

181. Betterle C, Rossi A, Dalla Pria S, Artifoni A, Pedini B, Gavasso S, Caretto A 1993 Premature ovarian failure: autoimmunity and natural history. Clin Endocrinol (Oxf) 39:35-43

182. Golonka JE, Goodman AD 1968 Coexistence of primary ovarian insufficiency, primary adrenocortical insufficiency and idiopathic hypoparathyroidism. J Clin Endocrinol Metab 28:79-82

183. Labarbera AR, Miller MM, Ober C, Rebar RW 1988 Autoimmune etiology in premature ovarian failure. Am J Reprod Immunol Microbiol 16:115-122

184. Blizzard RM, Chee D, Davies W 1967 The incidence of adrenal and other antibodies in sera of patients with idiopathic adrenal insufficiency (Addison's disease). Clin Exp Immunol 2:19-30

185. Irvine WJ, Chan MMW, Scarth L, Kolb FO, Hartog M, Bayliss RIS, Drury MI 1968 Immunological aspects of premature ovarian failure associated with idiopathic Addison's disease. Lancet 2:883887

186. Sotsiou F, Bottazzo GF, Doniach D 1980 Immunofluorescence studies on autoantibodies to steroid-producing cells, and to germline cells in endocrine diseases and infertility. Clin Exp Immunol 39:97-111

187. Elder M, MacLaren N, Riley W 1981 Gonadal autoantibodies in patients with hypogonadism and/or Addison's disease. J Clin Endocrinol Metab 52:1137-1142

188. Ahonen P, Miettinen A, Perheentupa J 1987 Adrenal and steroidal cell antibodies in patients with autoimmune polyglandular disease type I and risk of adrenocortical and ovarian failure. J Clin Endocrinol Metab 64:494-500

189. McNatty KP, Short RV, Barnes EW, Irvine WJ 1975 The cytotoxic effect of serum from patients with Addison's disease and autoimmune ovarian failure on human granulosa cells in culture. Clin Exp Immunol 22:378-384

190. Furmaniak J, Kominami S, Asawa T, Wedlock N, Colls J, Smith BR 1994 Autoimmune Addison's disease - evidence for a role of steroid 21-hydroxylase autoantibodies in adrenal insufficiency. J Clin Endocrinol Metab 79:1517-1521

191. Winqvist O, Karlsson FA, Kämpe O 1992 21-Hydroxylase, a major autoantigen in idiopathic Addison's disease. Lancet 339:1559-1562

192. Baumann-Antczak A, Wedlock N, Bednarek J, Kiso Y, Krishnan H, Fowler S, Smith BR, Furmaniak J 1992 Autoimmune Addison's disease and 21-hydroxylase. Lancet 340:429-430

193. Krohn K, Uibo R, Aavik E, Peterson P, Savilahti K 1992 Identi- fication by molecular cloning of an autoantigen associated with Addison's disease as steroid 17- $\alpha$-hydroxylase. Lancet 339:770-773

194. Winqvist O, Gustafsson J, Rorsman F, Karlsson FA, Kämpe O 1993 Two different cytochrome p450 enzymes are the adrenal antigens in autoimmune polyendocrine syndrome type I and Addison's disease. J Clin Invest 92:2377-2385

195. Uibo R, Perheentupa J, Ovod V, Krohn KJ 1994 Characterization of adrenal autoantigens recognized by sera from patients with autoimmune polyglandular syndrome (APS) type I. J Autoimmun 7:399-411

196. Uibo R, Aavik E, Peterson P, Perheentupa J, Aranko S, Pelkonen R, Krohn KJ 1994 Autoantibodies to cytochrome p450 enzymes p450 scc, p450c17, and p450c21 in autoimmune polyglandular disease types I and II and in isolated Addison's disease. J Clin Endocrinol Metab 78:323-328

197. Velloso LA, Winqvist O, Gustafsson J, Kämpe O, Karlsson FA 1994 Autoantibodies against a novel $51 \mathrm{kDa}$ islet antigen and glutamate decarboxylase isoforms in autoimmune polyendocrine syndrome type I. Diabetologia 37:61-69

198. Song YH, Connor EL, Muir A, She SX, Zorovich B, Derovanesian D, Maclaren N 1994 Autoantibody epitope mapping of the 21hydroxylase antigen in autoimmune Addison's disease. J Clin Endocrinol Metab 78:1108-1112

199. Winqvist O, Gustafsson J, Rorsman F, Karlsson FA, Kampe O 1993 Two different cytochrome P450 enzymes type I are the adrenal antigens in autoimmune antigens in autoimmune polyendocrine syndrome type I and Addison's disease. J Clin Invest 92:2377-2385

200. Bannatyne P, Russell P, Shearman RP 1990 Autoimmune oöphoritis: a clinicopathologic assessment of 12 cases. Int J Gynaecol Pathol 9:191-207

201. Sedmak DD, Hart WR, Tubbs RR 1987 Autoimmune oöphoritis: a histopathologic study involved ovaries with immunologic characterization of the mononuclear cell infiltrate. Int J Gynecol Pathol 6:73-81

202. Gloor E, Hurlimann J 1984 Autoimmune oöphoritis. Am J Clin Pathol 81:105-109

203. Edmonds M, Lamki L, Killinger DW, Volpe R 1973 Autoimmune thyroiditis, adrenalitis and oöphoritis. Am J Med 54:782-787

204. Bottazzo GF, Mirakian R, Drexhage HA 1996 Adrenalitis, oöphoritis and autoimmune polyglandular disease. In: Rich RR et al. (eds) Clinical Immunology, Principles and Practice. Mosby, St. Louis, MO, chapter 100, pp 1523-1536

205. Ahonen P, Koskimies S, Lokki ML, Tiilikainen A, Perheentupa J 1988 The expression of autoimmune polyglandular disease type 1 appears associated with several HLA-A antigens but not with HLA-DR. J Clin Endocrinol Metab 66:1152-1157

206. Aaltonen J, Björses P, Sandkuijl L, Perheentupa J, Peltonen L 1994 An autosomal locus causing autoimmune disease: autoimmune polyglandular disease type 1 assigned to chromosome 21. Nat Genet 8:83-87

207. Yamakawa K, Mitchell S, Hubert R, Chen XN, Colbern S, Huo YK, Gadomski C, Kim UJ, Korenberg JR 1995 Isolation and characterization of a candidate gene for progressive myoclonus epilepsy on 21q22.3. Hum Mol Genet 4:709-716

208. Dewhurst CJ, De Koos EB, Ferreira HP 1975 The resistant ovary syndrome. Br J Obstet Gynecol 82:341-345

209. Zourlas PA, Comninos AC 1971 Primary amenorrhea with normally developed secondary sex characteristics. Obstet Gynecol 38: 298-303

210. Koninckx PR, Brosens IA 1977 The "gonadotropin-resistant ovary" syndrome as a cause of secondary amenorrhea and infertility. Fertil Steril 28:926-931

211. Kim MH 1974 "Gonadotropin-resistant ovaries" syndrome in association with secondary amenorrhea. Am J Obstet Gynecol 120: 257-263

212. Kuki S, Morgan RL, Tucci JR 1981 Myasthenia gravis and premature ovarian failure. Arch Intern Med 141:1230-1232

213. Escobar ME, Cigorraga SB, Chiauzzi VA, Charreau EH, Rivarola MA 1982 Development of the gonadotrophic resistant ovary syndrome in myasthenia gravis: suggestion of similar autoimmune mechanisms. Acta Endocrinol (Copenh) 99:431-436

214. Shangold MM, Turksoy RN, Bashford RA, Hammond CB 1977 
Pregnancy following the "insensitive ovary syndrome". Fertil Steril 28:1179-1181

215. Maxson WS, Wentz AC 1983 The gonadotropin resistant ovary syndrome. Semin Reprod Endocrinol 1:147-160

216. Tsirigotis M, Craft IL 1994 Benign thymoma and resitant ovary syndrome. Br J Obstet Gynaecol 101:350-352

217. Dahl KD, Biesak TA, Hsueh AJ 1988 Naturally occurring antihormones: secretion of FSH antagonists by women treated with GnRH analog. Science 239:72-74

218. Sluss PM, Schneyer AL 1992 Low molecular weight follicle-stimulating hormone receptor binding inhibitor in sera from premature ovarian failure patients. J Clin Endocrinol Metab 74:1242-1246

219. Muechler EK, Huang KE, Schenk E 1991 Autoimmunity in premature ovarian failure. Int J Fertil 36:99-103

220. Moncayo-Naveda HE, Moncayo R, Benz R, Wolf A, Lauritzen C 1989 Organ-specific antibodies against ovary in patients with system lupus erythematosus. Am J Obstet Gynecol 160:1227-1229

221. de Moraes-Ruehsen M, Blizzard RM, Garcia-Bunuel R, Jones GS 1972 Autoimmunity and ovarian failure. Am J Obstet Gynecol 112:693-703

222. Friedman S, McCormick JN, Fudenberg HH, Goldfien A 1972 Ovarian antibodies in disorders of ovarian function. Clin Immunol Immunopathol 1:94-103

223. Rabinowe SL, Ravnikar VA, Dib SA, George KL, Dluhy RG 1989 Premature menopause: monoclonal antibody defined T lymphocyte abnormalities and antiovarian antibodies. Fertil Steril 51:450454

224. Pekonen F, Siegberg R, Makinen T, Miettinen A, Yli-Korkala O 1986 Immunological disturbances in patients with premature ovarian failure. Clin Endocrinol (Oxf) 25:1-6

225. Mathur S, Peress MR, Williamson HO, Youmans CD, Maney SA, Garvin AJ, Rust PF, Fudenberg HH 1982 Autoimmunity to endometrium and ovary in endometriosis. Clin Exp Immunol 50: 259-266

226. Coulam CB, Ryan RJ 1979 Premature menopause. I. Etiology. Am J Obstet Gynecol 133:639-643

227. Coulam CB, Ryan RJ 1985 Prevalence of circulating antibodies directed towards ovaries among women with premature ovarian failure. Am J Reprod Immunol Microbiol 9:23-24

228. Damewood MD, Zacur HA, Hoffman GJ, Rock JA 1986 Circulating antiovarian antibodies in premature ovarian failure. Obstet Gynecol 68:850-854

229. Luborsky JL, Visintin I, Boyers SP, Asari T, Caldwell B, DeCherney A 1990 Ovarian antibodies detected by immobilized antigen immunoassay in patients with premature ovarian failure. J Clin Endocrinol Metab 70:69-75

230. DeGroot LJ, Quintans J 1989 The causes of autoimmune thyroid disease. Endocr Rev 10:537-562

231. Bottazzo GF, Todd I, Mirakian R, Belfiore A, Pujol-Borrell R 1986 Organ-specific autoimmunity: a 1986 overview. Immunol Rev 94: 137-169

232. Austin GE, Coulam CB, Ryan RJ 1979 A search for antibodies to luteinizing hormone receptors in premature ovarian failure. Mayo Clin Proc 54:394-400

233. Chiauzzi V, Cigorraga S, Escobar ME, Rivarola MA, Charreau EH 1982 Inhibition of follicle-stimulating hormone receptor binding by circulating immunoglobulins. J Clin Endocrinol Metab 54:12211228

234. Tang VW, Faiman C 1983 Premature ovarian failure: a search for circulating factors against gonadotropin receptors. Am J Obstet Gynecol 146:816-821

235. van Weissenbruch MM, Hoek A, van Vliet-Bleeker I, Schoemaker J, Drexhage H 1991 Evidence for existence of immunoglobulins that block ovarian granulosa cell growth in vitro. A putative role in resistant ovary syndrome? J Clin Endocrinol Metab 73:360-367

236. Wheatcroft NJ, Toogood AA, Li TC, Cooke ID, Weetman AP 1994 Detection of antibodies to ovarian antigens in women with premature ovarian failure. Clin Exp Immunol 96:122-128

237. Anasti JN, Flack MR, Froelich J, Nelson LM 1995 The use of human recombinant gonadotropin receptors to search for immunoglobulin G-mediated premature ovarian failure. J Clin Endocrinol Metab 80:824-828
238. Moncayo H, Moncayo R, Bentz R, Wolf A, Lauritzen C 1989 Ovarian failure and autoimmunity. Detection of autoantibodies directed against both the unoccupied luteinizing hormone/human chorionic gonadotropin receptor and the hormone-receptor complex of bovine corpus luteum. J Clin Invest 84:1857-1865

239. Moncayo R, Moncayo H, Dapunt O 1990 Immunological risks of IVF (letter). Lancet 335:180

240. Jia XC, Oikawa M, Bo M, Tanaka T, Ny T, Boime I, Hsueh AJ 1991 Expression of human luteinizing hormone receptor: interaction with LH and chorion gonadotropin from human but not equine, rat, and ovine species. Mol Endocrinol 5:759-768

241. Tilly JL, Aihara T, Nishimori K, Jia XC, Billig H, Kowalski KI, Perlas EA, Hsueh AJ 1992 Expression of recombinant human follicle-stimulating hormone receptor: species-specific ligand binding, signal transduction, and identification of multiple ovarian messenger ribonucleic acid transcripts. Endocrinology 131:799806

242. Kamada M, Daitoh T, Mori K, Maeda N, Hirano K, Irahara M, Aono T, Mori T 1992 Etiological implication of autoantibodies to zona pellucida in human female infertility. Am J Reprod Immunol 28:104-109

243. Jansen A 1995 Dendritic Cells, Macrophages in Insulin Dependent Diabetes Mellitus. Thesis, Rotterdam

244. Miyake T, Sato Y, Takeuchi S 1987 Implications of circulating autoantibodies and peripheral blood Iymphocytes for the genesis of premature ovarian failure. J Reprod Immunol 12:163-171

245. Ho PC, Tang GW, Fu KH, Fan MC, Lawton JW 1988 Immunologic studies in patients with premature ovarian failure. Obstet Gynecol 71:622-626

246. Mignot MH, Drexhage HA, Kleingeld M, Van de Plassche-Boers EM, Rao BR, Schoemaker J 1989 Premature ovarian failure. II. Considerations of cellular immunity defects. Eur J Obstet Gynecol Reprod Biol 30:67-72

247. Nelson LM, Kimzey LM, Merriam GR, Fleisher TA 1992 Increased peripheral T Iymphocyte activation in patients with karyotypically normal spontaneous premature ovarian failure. Fertil Steril 55: 1082-1087

248. Hoek A, van Kasteren Y, de Haan-Meulman M, Hooijkaas H, Schoemaker J, Drexhage HA 1995 Analysis of peripheral blood Iymphocyte subsets, NK cells, and delayed type hypersensitivity skin test in patients with premature ovarian failure. Am J Reprod Immunol 33:495-502

249. Jackson RA, Haynes BF, Burch WM, Shimizu K, Bowring MA, Eisenbarth GS 1984 la + T cells in new onset Graves' disease. J Clin Endocrinol Metab 59:187-190

250. Jackson RA, Morris MA, Haynes BF, Eisenbarth GS 1982 Increased circulating la antigen-bearing $\mathrm{T}$ cells in type I diabetes mellitus. N Engl J Med 306:785-788

251. Rabinowe SL, Jackson RA, Dluhy RG, Williams GH 1984 la $+\mathrm{T}$ Iymphocytes in recently diagnosed idiopathic Addison's disease. Am J Med 77:597-601

252. Ho PC, Tang GWK, Lawton JW 1993 Lymphocyte subsets and serum immunoglobulins in patients with premature ovarian failure before and after oestrogen replacement. Hum Reprod 8:714-716

253. Marazuela M, Vargas JA, Alvarez-Mon M, Albarran F, Lucas T, Durantez A 1995 Impaired natural killer cytotoxicity in peripheral blood mononuclear cells in Graves' disease. Eur J Endocrinol 132: $175-180$

254. Jansen A, van Hagen M, Drexhage HA 1995 Defective maturation and function of antigen-presenting cells in type I diabetes. Lancet 345:491-493

255. Tas M, de Haan-Meulman M, Kabel PJ, Drexhage HA 1991 Defects in monocyte polariztion and dendritic cell clustering in patients with Graves' disease. A putative role for a non-specific immunoregulatory factor related to retroviral P15E. Clin Endocrinol (Oxf) 34:441-448

256. Hoek A, van Kasteren Y, de Haan-Meulman M, Schoemaker J, Drexhage HA 1993 Dysfunction of monocytes and dendritic cells in patients with premature ovarian failure. Am J Reprod Immunol 30:207-217

257. Mathur S, Melchers III JT, Ades EW, Williamson HO, Fudenberg HH 1980 Anti-ovarian and anti-lymphocyte antibodies in patients with chronic vaginal candidiasis. J Reprod Immunol 2:247-262 
258. Walfish PG, Gottesman IS, Shewchuk AB, Bain J, Hawe BS, Farid NR 1983 Association of premature ovarian failure with HLA antigens. Tissue Antigens 21:168-169

259. Anasti JN, Adams S, Kimzey LM, Defensor RA, Zachary AA, Nelson LM 1994 Karyotypically normal spontaneous premature ovarian failure: evaluation of association with class II major histocompatibility complex. J Clin Endocrinol Metab 78:722-723

260. Jaroudi KA, Arora M, Sheth KV, Sieck UV, Willemsen WN 1994 Human leucocyte antigen typing and associated abnormalities in premature ovarian failure. Hum Reprod 9:2006-2009

261. Sakaguchi S, Sakaguchi N 1989 Organ-specific autoimmune disease induced in mice by elimination of T cell subsets. V. Neonatal administration of cyclosporin A causes autoimmune disease. J Immunol 142:471-480

262. Taguchi O, Takahashi T, Masao S, Namikawa R, Matshyama M, Nishizuka Y 1986 Development of multiple organ-localized autoimmune diseases in nude mice after reconstitution of $\mathrm{T}$ cell function by rat fetal thymus graft. J Exp Med 164:60-71

263. Sakaguchi S, Sakaguchi N 1990 Thymus and autoimmunity: capacity of the normal thymus to produce pathogenic self-reactive $\mathrm{T}$ cells and conditions required for their induction of autoimmune disease. J Exp Med 172:537-545

264. Smith H, Lou YH, Lacy P, Tung KS 1992 Tolerance mechanism in experimental ovarian and gastric autoimmune diseases. J Immunol 149:2212-2218

265. Jankovic BD, Markovic BM, Petrovic S, Isakovic K 1973 Experimental autoimmuno-oophoritis in the rat. Eur J Immunol 3:375377

266. Damjanovic M, Janovic BD 1989 Experimental autoimmune oophoritis. 1. Inhibition of fertility in rats isoimmunized with homogenates of the ovary. Am J Reprod Immunol 20:1-8

267. Ivanova M, Bourneva V, Gitsov L, Angelova Z 1984 Experimental immune oophoritis as a model for studying the thymus ovary interaction. I. Morphological studies. Am J Reprod Immunol 6:99106

268. Damjanovic M 1991 Experimental autoimmune oophoritis. 11. Both Iymphoid cells and antibodies are successful in adoptive transfer. Autoimmunity 9:217-223

269. Wood DM, Liu C, Dunbar BS 1981 The effect of alloimmunization and heteroimmunization with zonae pellucidae on fertility in rabbits. Biol Reprod 25:439 450

270. Skinner SM, Mills T, Kirchick HJ, Dunbar BS 1984 Immunization with zona pellucida proteins results in abnormal ovarian follicular differentiation and inhibition of gonadotropin-induced steroid secretion. Endocrinology 115:2418-2432

271. Anonymous 1986 Case records of the Massachusett's General hospital. Weekly clinicopathological exercises. Case 46-1986: a 26year-old woman with secondary amenorrhea. N Engl J Med 315: 1336-1343

272. Anonymous 1987 Case records of the Massachusett's General Hospital. Case 46-1987: a 31-year-old woman with secondary amenorrhea. N Engl J Med 317:1270-1278

273. Rhim SH, Millar SE, Robey F, Luo AM, Lou YH, Yule T, Allen P, Dean J, Tung KS 1992 Autoimmune diseases of the ovary induced by ZP3 peptide from the mouse zona pellucida. J Clin Invest 89:28-35

274. Dean J 1992 Biology of mammalian fertilization: role of the zona pellucida. J Clin Invest 89:1055-1059

275. Lou Y, Tung KS 1993 T cell peptide of a self-protein elicits autoantibody to the protein antigen. Implications for specificity and pathogenetic role of antibody in autoimmunity. J Immunol 151: 5790-5799

276. Luo AM, Garza KM, Hunt D, Tung KS 1993 Antigen mimicry in autoimmune disease: $\times$ sharing of amino acid residues critical for pathogenic T cell activation. J Clin Invest 92:2117-2123

277. Chamberlin ME, Dean J 1990 Human homolog of the mouse sperm receptor. Proc Natl Acad Sci USA 87:6014-6018

278. Taguchi O, Nishizuka Y, Sakakura T, Kojima A 1980 Autoimmune oophoritis in thymectomized mice: detection of circulating antibodies against oocytes. Clin Exp Immunol 40:540-553

279. Miyake T, Taguchi O, Ikeda H, Sato Y, Takeuchi S, Nishizuka Y 1988 Acute oocyte loss in experimental autoimmune oophoritis as a possible model of premature ovarian failure. Am J Obstet Gynecol 158:186-192

280. Tung KS, Smith S, Teuscher C, Cook C, Anderson RE 1987 Murine autoimmune oophoritis, epididymo-orchitis, and gastritis induced by day 3 thymectomy. Am J Pathol 126:293-302

281. Taguchi O, Nishizuka Y 1980 Autoimmune oophoritis in the thymectomized mice: T cell requirement in the adoptive cell transfer. Clin Exp Immunol 42:324-331

282. Sakaguchi S, Takahashi T, Nishizuka Y 1982 Study on cellular events in postthymectomy autoimmune oophoritis in mice. 1. Requirement of Lyt-1 effector cells for oocytes damage after adoptive transfer. J Exp Med 156:1565-1576

283. Smith H, Sakamoto Y, Kasai K, Tung KSK 1991 Effector and regulatory cells in autoimmune oophoritis elicited by neonatal thymectomy. J Immunol 147:2928-2933

284. Wardell BB, Michael SD, Tung KS, Todd JA, Blankenhorn EP, McEnter K, Sudweeks JD, Hansen WK, Meeker ND, Griffith JS, Livingstone KD, Teuscher C 1995 Aod 1, the immunoregulatory locus controlling abrogation of tolerance in neonatal thymectomyinduced autoimmune ovarian dysgenesis, maps to mouse chromosome 16. Proc Natl Acad Sci USA 92:4758-4762

285. Meeker ND, Hickey WF, Korngold R, Hansen WK, Sudweeks JD, Wardell BB, Griffith JS, Teuscher C 1995 Multiple loci govern the bone marrow-derived immunoregulatory mechanism controlling dominant resistance to autoimmune orchitis. Proc Natl Acad Sci USA 92:5684-5688

286. Smith H, Chen IM, Kubo R, Tung KS 1989 Neonatal thymectomy results in a repertoire enriched in T cells deleted in adult thymus. Science 245:749-752

287. Miller ME, Chatten J 1967 Ovarian changes in ataxia telangiectasia. Acta Paediatr Scand 56:559-561

288. Cowchock FS, McCabe JL, Montgomery BB 1988 Pregnancy after corticosteroid administration in premature ovarian failure (polyglandular endocrinopathy syndrome). Am J Obstet Gynecol 158:118-119

289. Blumenfeld Z, Halachmi S, Peretz BA, Shmuel Z, Golan D, Makler A, Brandes JM 1993 Premature ovarian failure. The prognostic application of autoimmunity on conception after ovulation induction. Fertil Steril 59:750-755

290. Corenblum B, Rowe T, Taylor PJ 1993 High-dose, short-term glucocorticoids for the treatment of infertility resulting from premature ovarian failure. Fertil Steril 59:988-991

291. Lundberg PO, Persson BH 1969 Disappearance of amenorrhea after thymectomy. Case report. Acta Soc Med Ups 74:206-208

292. Bateman BG, Nunley Jr WC, Kitchin III JD 1983 Reversal of apparent premature ovarian failure in a patient with myastenia gravis. Fertil Steril 39:108-110

293. Irvine WJ 1980 Autoimmunity in endocrine disease. Recent Prog Horm Res 36:509-556

294. Coulam CB, Kempers RD, Randall RV 1981 Premature ovarian failure: evidence for the autoimmune mechanism. Fertil Steril 36: $238-240$

295. Rabinowe SL, Berger MJ, Welch WR, Dluhy RG 1986 Lymphocyte dysfunction in autoimmune oophoritis. Resumption of menses with corticosteroids. Am J Med 81:347-350

296. Wolfe CD, Stirling RW 1988 Premature menopause associated with autoimmune oophoritis. Case report. Br J Obstet Gynecol 95:630-632

297. Biscotti CV, Hart WR, Lucas JG 1989 Cystic ovarian enlargement resulting from autoimmune oophoritis. Obstet Gynecol 74:492-495

298. Lonsdale RN, Roberts PF, Trowell JE 1991 Autoimmune oophoritis associated with polycystic ovaries. Histopathology 19:77-81

299. Russell P, Bannatyne P, Shearman RP, Fraser IS, Corbett P 1982 Premature hypergonadotropic ovarian failure: clinicopathological study of 19 cases. Int J Gynecol Pathol 1:185-201

300. Friedman Cl Gurgen-Varol F, Lucas J, Neff J 1987 Persistent progesterone production associated with autoimmune oophoritis. A case report. J Reprod Med 32:293-296

301. Emperaire JC, Audebert A, Greenblatt RB 1970 Premature ovarian failure. Report of seven cases. Am J Obstet Gynecol 108:445-449

302. Zarate A, Karchmer S, Gomez E, Castelazo-Ayala L 1970 Premature menopause. A clinical, histologic, and cytogenetic study. Am J Obstet Gynecol 106:110-114 
303. Sharf M, Israeli I, Graff G 1972 The value of ovarian biopsy in the diagnosis and treatment of amenorrhoea related sterility. Obstet Gynecol 39:89-94

304. Falk RJ 1977 Euestrogenic ovarian failure. Fertil Steril 28:502-503

305. Duignan NM, Shaw RW, Glass MR, Butt WR, Edwards RL 1978 Sex hormone levels and gonadotrophin release in premature ovarian failure. Br J Obstet Gynaecol 85:862-867

306. Board JA, Redwine AO, Moncure CW, Frable WJ, Taylor JR 1979 Identification of differing etiologies of clinically diagnosed premature menopause. Am J Obstet Gynecol 134:936-944

307. Menon V, Edwards RL, Butt WR, Bluck M, Lynch SS 1984 Review of 59 patients with hypergonadotrophic amenorrhoea. Br J Obstet Gynaecol 91:63-66

308. Aiman J, Smentek C 1985 Premature ovarian failure. Obstet Gynecol 66:9-14

309. Rebar RW, Connolly HV 1990 Clinical features of young women with hypergonadotropic amenorrhea. Fertil Steril 53:804-810

310. Behrman SJ 1964 Discussion. Am J Obstet Gynecol 89:94-95

311. Vallotton MB, Forbes AP 1969 Premature menopause in autoimmune diseases. Lancet 1:156-157

312. Ayala A, Canales ES, Karchmer S, Alarcon D, Zarate A 1979
Premature ovarian failure and hypothyroidism associated with sicca syndrome. Obstet Gynecol 53[Suppl 3]:985-1015

313. Collen RJ, Lippe BM, Kaplan SA 1979 Primary ovarian failure, juvenile rheumatoid arthritis, and vitiligo. Am J Dis Child 133: $598-600$

314. Williamson HO, Phansey SA, Mathur S, Mathur RS, Baker ER, Fundenberg HH 1980 Myasthenia gravis, premature menopause, and thyroid autoimmunity. Am J Obstet Gynecol 137:893-901

315. Coulam CB, Lufkin EG 1981 Absence of adrenal failure in the polyglandular failure syndrome with primary ovarian failure. Fertil Steril 35:365-366

316. Mignot MH, Schoemaker J, Kleingeld M, Rao BR, Drexhage HA 1989 Premature ovarian failure. I. The association with autoimmunity. Eur J Obstet Gynecol Reprod Biol 30:59-66

317. Wolffenbuttel BH, Weber RF, Prins ME, Verschoor L 1987 Premature ovarian failure and autoimmune hypothyroidism in the absence of Addison's disease. Neth J Med 30:128-134

318. Belvisi L, Bombelli F, Sironi L, Doldi N 1993 Organ-specific autoimmunity in patients with premature ovarian failure. J Endocrinol Invest 16:889-892

\section{Advances in Endocrinology and Metabolism}

Dates: $\quad$ March 21-22, 1997

Location: Holiday Inn-Union Square, San Francisco

Sponsor: Department of Medicine, University of California, San Francisco

Contact: 415-476-5208, Postgraduate Programs, Box 0656, University of California-San Francisco, San Francisco, CA 94143-0656

Credit: $\quad 13.0$ hours of Category 1 AMA credit

Fees: \$295/physicians; \$165/allied health professionals (\$430/235 if also registering for "Diabetes Update" on March 20; see p. 25 for announcement) 